\title{
İSRÂİLIYYÂT KAVRAMININ OLUŞUM VE OLGUNLAŞMA SÜRECİ
}

\section{Ertuğrul Döner*}

\begin{abstract}
Özet
İslam dini ve medeniyeti temelde Kur'an ve Sünnet'e dayalı olmakla birlikte kültür ve gelenek açısından özellikle Yahudilik ve Hıristiyanlıkla irtibatlıdır. Bu irtibat Kur'an'ı Kerim tarafindan da vurgulanır. Gerek Kur'an'ın Tevrat ve İncil gibi kitaplara atıfla kendini "musaddık” olarak nitelendirmesi, gerek Hz. Peygamber'in vahiy ve risalet zincirinin son halkası olduğuna işaret edilmesi ve gerekse Kur'an kıssalarının önemli bir kısmının özellikle İsrailoğulları ve Yahudilerle ilgili olması İslam ile Ehl-i kitap geleneği arasındaki irtibatın boyutları hakkında az çok bir fikir verir mahiyettedir. Bu çalışma Yahudilik ve Hıristiyanlık gibi farklı din ve kültürlerden İslamî literatüre, özellikle de tefsir edebiyatına giren rivayetlere atıfla kullanılan İsrâiliyyât kavramı ve bu kavramın anlam alanı gibi konuların incelenmesine dairdir. Bu bağlamda İsrâiliyyât kelimesinin kökeni, anlam içeriği, ilk kez hangi kaynaklarda ve hangi anlamlarda kullanıldığı ve terimleşme/kavramlaşma süreci hakkında birtakım bilgiler sunulmuş, bununla birlikte özellikle erken ve klasik dönemlerdeki İsrâiliyyât algısı üzerinde durulmuștur.
\end{abstract}

Anahar Kelimeler: İsrâiliyyât, Yahudilik, Hıristiyanlık, Selefîlik, Tefsir.

\section{The Process of Formation and Maturing of the Concept of Isra'iliyyat}

\begin{abstract}
Althought the religion and civilization of Islam are essentially based on Qur'ân and Sunnah, they are related to Judaism and Christianity in terms of culture and tradation. This relation is also emphasized by Qur'an. All that Qur'an describes itself as the affirmative "al-musaddik" with reference to Torah and Bible, and it is referred (by Qur'an) that the Prophet is the last ring of the apocalyptic and prophetic chain, and the major part of Qur'anic story/qisas is related to the children of Israel (Bani Israel) and Judaists in particular, gives more or less information about dimensions of the relationship Islam and Ahl al-Qitab. This study is about examination of the concept and semitic fields Isra'iliyyat specified with reference to the riwayats that have entered to Islamic literature, tafsir in particular, from different religions and cultures such as Judaism and Christianity. We give, in this context, some information about the etymology of Isra'iliyyat, and its content, and that in which work it has appeared at the first time, and in which meaning it has been used, and its process of conceptualization. Also we put emphasis on Isra'iliyyat perception in the early and classical terms.
\end{abstract}

Keywords: Isra'iliyyat, Judaism, Christianity, Salafism, Tafsir.

\footnotetext{
*Dr., Çukurova Üniversitesi İlahiyat Fakültesi Tefsir Anabilim Dalı, edoner@cu.edu.tr.
} 


\section{İsrâiliyyât Kelimesinin Kökeni ve Temel Anlam İçeriği}

Modern dönem Kur'an ve tefsir araştırmalarındaki genel yaklaşıma göre İsrâiliyyât bilhassa rivayet ağırlıklı tefsir edebiyatındaki temel sorunların başında gelmektedir. İsrâiliyyât kelimesinin ortaya çıkışı, zaman içerisinde terimleşip yan anlamlar kazanması ve ciddi bir tefsir problemi olarak algılanması gibi meselelere geçmeden önce kelimenin kökenini incelemek, klasik ve modern dönemde bu konuya tahsis edilen ilmî çalışmalardaki genel bakış açısı hakkında birtakım bilgiler vermek, bunun için de öncelikle "İsrâiliyyât"ın nasıl tanımlandığı ve İsrâiliyyât'tan ne anlaşıldığı gibi birkaç husus üzerinde durmak gerekmektedir.

İsrâiliyyât, isrâiliyye (إسرائيلية) kelimesinin çoğulu olup terimsel olarak İsrâilî bir kaynaktan rivayet edilen kıssa veya hâdise anlamına gelir. ${ }^{1}$ İsrâiliyye, kök itibariyle “İsrâîll”den (إسرائيل) türemiş bir kelimedir. İsrail ise Eski Ahit’te Hz. Yakub’un ismi veya lakabı olarak zikredilmiştir. Kur'an'ı Kerim'de Yahudiler birçok kez Hz. Yakub'a nispetle "Benî İsrâîl” (بني إسرائيل) (İsrailoğulları) şeklinde geçmiş, bu isim ve isimlendirme Eski Ahit’te "Bene(y) Yisrael” şeklinde ifade edilmiştir. ${ }^{2}$

Müslüman dilcilerin genel kabul ve kanaatine göre İbrancada "isrâ" kelimesi kul, "îl” kelimesi Allah anlamına gelir. "İsrâ" kelimesinin "Allah'1n seçtiğì", “îl” kelimesinin "Allah" anlamına geldiği veya "isrâ"nın "sağlam yapmak" ve "bağlamak" anlamlarına geldiği yönünde görüşler de zikredilir. Buna göre İsrâîl kelimesi, "Allah tarafından sağlam ve güçlü bir şekilde yaratılmış" gibi bir anlam içerir. ${ }^{3}$

İsrâîl kelimesinin kökenini daha spesifik biçimde incelemek gerekirse, Kur'an kelimeleri üzerine kapsamlı bir çalışması bulunan Mustafavî (ö. 2005) “İsrâîl” kelimesinin İbrancadaki anlamının Arapçadaki “esr” (أَسْر) kelimesine karşılık geldiğinden söz etmiştir. Buna göre İsrâîl, “Allah’1n denetim ve gözetim altında tuttuğu, kendisine bağlı kıldı̆̆ı kimse" demektir ve dolayısıyla Arapçadaki “Abdullah"

\footnotetext{
${ }^{1}$ Muhammed Hüseyin ez-Zehebî, el-İsrâiliyyât fi' t-Tefsîr ve'l-Hadîs, Dımeşk 1985, s. 19; Remzi Na'nâa, el-İsrâiliyyât ve Eseruhâ fì Kütübi’t-Tefsîr, Dımeşk-Beyrut 1970, s. 71; Abdullah Aydemir, Tefsirde Ísrâiliyyat, Beyan Yayınları, İstanbul 2000, s. 29.

${ }^{2}$ Yusuf Besalel, "Yisrael”, Yahudilik Ansiklopedisi, Gözlem Gazetecilik Basın ve Yayın A.Ş., İstanbul 2002, III, 791; Ömer Faruk Harman, “İsrail (Benî İsrail)”, DİA, İstanbul 2001, XXIII, 194.

${ }^{3}$ Ebû Abdillah Muhammed el-Kurtubî, el-Câmi' li Ahkâmi'l-Kur'ân, Beyrut 1988, I, 226.
} 
kelimesine yakın bir anlam örgüsüne sahiptir. ${ }^{4}$

Muhibbî de (ö. 1111/1699) diğer birçok Müslüman dilci gibi İsrâîl kelimesinin İbranca olduğunu kabul etmiş ve kelimenin "Allah dostu”, “Allah'ın kulu”, “Allah adamı" manalarına geldiğini söylemiştir. ${ }^{5}$ Cevâlikî (ö. 540/1145) ise kelimenin Arap diline Süryanca'dan geçtiği yolunda bir görüşten söz etmiştir. ${ }^{6}$ Müsteşrik Arthur Jeffery (ö. 1959) de İbranca kabul ettiği kelimenin köküne dair birtakım farklı yaklaşımlar bulunduğuna dikkat çekmiştir. ${ }^{7}$

Kurtubî (ö. 671/1273) “İsrâîl” kelimesinin aslının Arapça olmadığını belirtmiş, bu sebeple kelimenin gayri munsarif (çekimsiz fiil) olduğunu söylemiştir. Kurtubî’ye göre bu kelime birçok farklı şekilde telaffuz edilir. Bunlardan birincisi hemzeli ve medli (uzatmali) Issrâîl (إسرائيل) şeklindedir. İkincisi ya'dan sonra medli ve hemsesiz Ísrâyîl (إسراييل), üçüncüsü hemzesiz ve medsiz olarak İsrâyil (إسرايل) şlindedir. Bunların dışında ya'sız ve fakat esreli bir hemzeyle Ísrâil (إسرائل), üstünlü bir hemze ile Ísrâel şeklinde telaffuz biçimleri de mevcuttur. Temimlilerin telaffuzu ise İsrâîn şeklindedir. ${ }^{8}$ Zemahşerî (ö. 538/1144) kelimenin köken itibariyle hangi dile ait olduğunu belirtmeksizin "Allah dostu”, “Allah'ın kulu” anlamlarında kullanıldığına, Ísrâîl (إسر إسئل) ve İsrâil (إنليل) şeklinde okunduğuna işaret etmiştir.9

Bazı müfessirler İsrâîl kelimesinin "gece yürüyüşü” anlamındaki serâ (سرى) kökünden türediğini belirtmişlerdir. Çünkü Hz. Yakub kardeşi Esav’dan kaçarken gece

\footnotetext{
${ }^{4}$ Allâme Hasan el-Mustafavî, et-Tahkîk fì Kelimâti'l-Kur'ân, Kahire-Beyrut 2009, I, 93.

${ }^{5}$ Muhammed Emin b. Fazlullah b. Muhibbillah ed-Dımeşkî el-Muhibbî, Kasdü's-Sebîl fi'l-Lugati'lArabiyye mine'd-Dahîl, thk. Osman Mahmûd Sinnî, Riyad 1994, s. 179; Ebû Câ'fer Muhammed b. Cerîr et-Taberî, Câmiü 'l-Beyân fî Tefsîri 'l-Kur'ân, Beyrut 1995, I, 355; Ebü'l-Fazl Muhammed b. Mükerrem b. Ali el-Ensârî İbn Manzûr, Lisânü'l-Arab, Beyrut 1994, XIV, 383; Aydemir, Tefsirde İsrâiliyyat, s. 29; Na'nâa, el-İsrâiliyyât ve Eseruhâ fì Kütübi't-Tefsîr, s. 72; Mustafa Ünver, Tefsirde Öteki: Celâleyn'de İsrâiliyyat, Sidre Yayınları, Samsun 2008, s. 34.

${ }^{6}$ Ebû Mansûr Mevhûb b. Ahmed b. Muhammed el-Cevâlikî, el-Muarreb mine'l-Kelâmi'l-A'cemi alâ Hurûfi'l-Mu'cem, thk. F. Abdürrahim, Dımeşk 1990, s. 106-107.

${ }^{7}$ Arthur Jeffery, The Foreign Vocabulary of The Qur'ân, Leiden, Boston 2007, s. 61.

${ }^{8}$ Kurtubî, el-Câmi' li Ahkâmi 'l-Kur'ân, I, 226.

${ }^{9}$ Ebu'l-Kâsım Cârullâh Mahmûd b. Ömer ez-Zemahşerî, el-Keşşâf 'an Hakâiki't-Tenzîl, Beyrut 1977, I, 275.
} 
yolculuğu yapmıştır. ${ }^{10}$ Kurtubî, Hz. Yakub'a İsrâîl adının verilmesini, onun Allah'a hicret ettiği vaktin bir gece vakti/yürüyüşüyle gerçekleşmiş olmasıyla ilişkilendirmiş ve bu sebeple ona İsrâîl adının verildiğini belirterek, İsrâîl adının “Allah'a gece vakti giden, yürüyen" anlamında kullanıldığını ifade etmiştir. ${ }^{11}$

Konuya Yahudi kaynakları açısından bakıldığında, Hz. Yakub'a İsrâîl adının verilmesi onun gece vakti yürüyüş yapmasından ziyade, aslında gece vakti bir adamla ya da mahiyeti tam olarak bilinemeyen bir varlıkla sabaha kadar güreşmesiyle ilgili olduğu söylenebilir. Tekvin'in bu konuyla ilgili pasajındaki anlatım şöyledir:

Yakub, Lavan'a olan hizmetini bitirdikten sonra ailesi ile Kenan topraklarına gitmek üzere yola çıktı. Yakub'un sahibi olduğu şeyleri kıskanan Lavan ve oğulları bunu fark ettilerse de, Tanrı Lavan'a rüyasında görünüp, Yakub'a engel olması gerektiğini açıkladı. Yakub dönüş yolculuğunda Esav'ın yaşadığı Edom kırlıklarına geldi. Yakub, Esav'ın öfkesinden çekindi. Gönderdiği büyük bir sürü ve habercisiyle Esav'ın gönlünü almaya çalıştı. $\mathrm{Bu}$ arada Yakub, ailesini ve mallarını Yobok Geçidi'nden karşıya ulaştırdı ve geri dönerek geceyi yalnız geçirdi. O gece karşısına çıkan tanımadığı bir varlıkla/adamla/melekle sabaha kadar güreşti ve yenişemedi. Adam/melek, Yakub'un uyluğundan başına dokunarak yaraladı ve artık Yakub'un adının Yisrael (Tanrıyla uğraşan) olduğunu söyleyerek onu kutsadı. ${ }^{12}$

Robert Winston'un aktardığı bilgilere göre kutsal kitap yorumcusu Rabbi Shlomo/Şelomo Yitzchaki (Rashi), ${ }^{13}$ güreşme fiilini anlatmak için kullanılan İbranca kelimenin kişilerin birbirine bağlanması, bedenlerin samimi bir şekilde birbirine sarılması gibi bir mana taşıdığını söylemiş, bunun belki de sevme eyleminden pek de farklı olmayan bir tecrübe olduğuna dikkat çekmiştir. Anlatıya göre Yakub ile gece

\footnotetext{
${ }^{10}$ Jeffery, The Foreign Vocabulary of The Qur'ân, s. 61; Muhammed Tâhir b. Âşûr, et-Tahrîr ve'tTenvîr, Tunus 1997, I, 449.

${ }^{11}$ Kurtubî, el-Câmi' li Ahkâmi'l-Kur'ân, II, 7.

${ }^{12}$ Tekvin 32/1-32. Nahum M. Sarna, Moses Aberbach, Haim Z'ew Hirschberg, “Jacob”, Encyclopaedia Judaica, Macmillan, USA 2007, XI, 17-25. Benzer bir anlatım için bkz. Yusuf Besalel, "Yaakov (Avinu)", Yahudilik Ansiklopedisi, III, 757.

${ }^{13}$ Rabbi Shlomo/Şelomo Yitzchaki (1040-1105) Fransa'nın Troyes kentinde yaşamış meşhur bir Eski Ahid ve Talmud yorumcusudur. İbranca grameri büyük bir titizlikle inceleyerek etkili yorumlar yapmış, Musevilik konusunda en önemli bilginlerden biri olarak kabul edilmiştir.
} 
boyunca güreşen yabancı kişi şafak sökmeden çekip gitmiş, böylece Yakub o kişinin yüzünü dahi görememiştir. O yabancı kişi, "Bırak beni gideyim, şafak söküyor." diyerek Yakub'tan izin istemiş, Yakub, 'Sen bana 'Allah senden razı olsun.' diyene dek seni bırakmayacağım." diye karşılık vermiştir. Yine o yabancı kişi Yakub'a, "Bundan böyle senin adın İsrail olacak.” demiştir. Bazı Yahudi kaynaklarında söz konusu kişinin Yakub'un koruyucu meleği ya da kurtarıcısı olduğundan söz edilmiştir. Başka birtakım yorumcular ise Yakub'un güreştiği kişinin bizzat Yakub'un kendisi olduğunu; rakibinin, şimdiye dek karşı karşıya kaldığı en büyük tehlikeyle karşılaşmak üzereyken gece boyunca ateşli bir şekilde boğuşan kendi vicdanından başkası olmadığını ileri sürmüştür. $^{14}$

Kur'an'1 Kerim'de kırk üç yerde kullanılan İsrâîl kelimesi genellikle "Benî İsrâîl”" şeklindeki terkiple Medine Yahudileriyle ilgili pasajlarda geçmekte, kelimenin tek başına geçtiği Âl-i İmrân 3/93 ve Meryem 19/58. ayetlerde ise Hz. Yakub'un ismi veya lakabı olarak zikredilmektedir. ${ }^{15}$ İbn Âşûr (ö. 1973), Benî İsrâîl terkibinin Hz. Yakub'un zürriyetine işaret ettiğini belirtmiş; ayrıca Yahudilere, "Eyyühe'l-Yehûd" şeklinde değil de "Yâ Benî İsrâ̂̂l” diye hitap edilmesini bir kabileye mensup olmakla ilişkilendirmiştir. Buna göre Yehûd bir dinin, bir inanç sisteminin adıdır. Bu din ve inanç sisteminde, Güney Arabistan kökenli bir Arap hanedanı olan Himyeriler gibi, İsrailoğullarına mensup olmayan insanlar ve topluluklar da yer alır. ${ }^{16}$ Benî İsrâîl terkibinin Kur'an'daki genel anlam ve kullanımı hem Hz. Yakub ve onunla nesep bağı bulunan tüm Yahudileri hem de Hz. Muhammed ile aynı dönemde Hicaz bölgesinde, bilhassa Medine ve çevresinde yaşayan Yahudilere işaret etmektedir. ${ }^{17}$ Nitekim birçok ayette, sözgelimi Bakara 2/47 ve 49. ayetlerde Medine Yahudilerine "Ey İsrailoğulları!" diye hitap edilmekte ve fakat bu hitap kapsamında Hz. Musa ve Firavun dönemindeki olaylar zikredilmektedir. Bu hitap tarzı Kur'an'1n Hz. Peygamber dönemindeki Medine Yahudileri ile geçmiş dönemlerdeki İsrailoğullarını özdeş kıldığını düşündürmektedir. Ancak buradaki özdeşlik muhtemelen nesep bağından ziyade, aynı din ve inanç

\footnotetext{
${ }^{14}$ Robert Winston, Tanrının Öyküsü, Say Yayınları, trc. Sinan Köseoğlu, İstanbul 2010, s. 21.

${ }^{15}$ Jeffery, The Foreign Vocabulary of The Qur'ân, s. 60; Ahmet Suphi Furat, "Ya'küb”, İA, İstanbul 1993, XIII, 351.

${ }^{16}$ İbn Âşûr, et-Tahrîr ve't-Tenvîr, I, 449; Jeffery, The Foreign Vocabulary of The Qur'ân, s. 294.

${ }^{17}$ Harman, "İsrail (Benî İsrail)”, DİA, XXIII, 194.
} 
sistemine mensubiyet veya Medine ve civarındaki Yahudilerin kendilerini soy olarak doğrudan İsrailoğullarına izafe etmesiyle ilgili olsa gerektir. Anlaşıldığı kadarıyla Kur'an bu hitaplarda Medine Yahudilerinin hangi soya mensup olup olmadiklarıyla ilgilenmemekte, aksine kendilerine yönelik algıları ve tanımlamaları üzerinden Yahudi muhataplarını, "Mademki İsrailoğullarına mensupsunuz; o halde size Musa döneminde büyük lütuflarda bulunduğumu ve o dönemlerde sizi cümle âleme üstün kıldığımı hatırlayın..." diyerek ilzam etmektedir. ${ }^{18}$

\section{İsrâiliyyât'la İlgili Tanımlar/Tanımlamalar}

İsrâiliyyât'ın tam olarak ne anlama geldiği, nasıl ve ne zaman ortaya çıktığ , terim olarak ilk ne zaman kullanılmaya başlandığı konusu başta İslam âlimleri olmak üzere birçok batılı araştırmacıyı meşgul etmiştir. Bu kelimenin sözlük anlamları üzerinde ciddi ihtilaflar bulunmamakla birlikte İsrâiliyyât teriminin başta İslam âlimleri olmak üzere şarkiyatçıların kullanımlarında oldukça müphem bir mahiyet arz etmesi, söz konusu terimin anlam ve aktarımlarında herkesin üzerinde ittifak edeceği bir tanım geliştirmeyi güçleştirmiştir. İsrâiliyyât'a dair çalışmalarda konuyla ilgili birbirine benzer tanım ve açıklamalar yapılmakla birlikte bu açıklamalardaki ifadeler daha ziyade olumsuz bir bakış açısını yansıtır mahiyettedir.

Remzi Na'nâa'ya göre İsrâiliyyât esas itibariyle İslam tefsir literatüründeki Yahudi anlatılarını ifade etmekle birlikte, hem Yahudi hem de Hıristiyan kültürünün tefsir kaynaklarındaki yansımaları için kullanılan bir terimdir. ${ }^{19}$ Benzer şekilde Abdullah Aydemir'e göre de bu terim her ne kadar tefsire girmiş Yahudi kültürünü ifade ediyor olsa da bunda bir inhisar düşünülemez. İslam'a ve özellikle tefsire girmiş Yahudi, Hıristiyan ve diğer dinlere ait kültür kalıntılarıyla, dinin gerek lehine gerek aleyhine uydurulup Hz. Peygamber'e ve onun muâsırları olan sahabe ve müteakip nesillere izafe edilen her türlü haber İsrâiliyyât kapsamında değerlendirilmelidir. Dolayısıyla İsrâiliyyât İslam'a yabancı olan her şeyi içerir. ${ }^{20}$

\footnotetext{
${ }^{18}$ Daha geniş bilgi için bkz. Necmettin Gökkır, “Kur’an Dilinde Ehl-i Kitap Kültürünün İzleri: SosyoLinguistik Bir Yaklaşım”, Tarihten Günümüze Kur'an'a Yaklaşımlar, 2010, s. 99-103.

${ }^{19} \mathrm{Na}$ 'nâa, el-İsrâiliyyât ve Eseruhâ fî Kütübi't-Tefsîr, s. 73.

${ }^{20}$ Aydemir, Tefsirde Isrâiliyyat, s. 29.
} 
Muhammed Hüseyin ez-Zehebî’nin konuyla ilgili değerlendirmeleri de aynı minvaldedir. Her ne kadar İsrâiliyyât denince ilk nazarda Yahudi kaynaklarından menkul rivayet malzemesi anlaşılsa da tefsir ve hadis âlimleri bu kelimeyi Yahudi kültürüne ait rivayet malzemesinden daha kapsamlı bir manada kullanmışlardır. Öyle ki Zehebî’ye göre bazı müfessirler İsrâiliyyât'ın anlam ve kapsam çerçevesini daha da genişletmiş, Yahudiler ile diğer İslam düşmanlarınca tefsir ve hadis kaynaklarına sokulan asılsız haberleri de bu kapsamda mütalaa etmişlerdir. Zira bunlar, tıpkı Garanik ve Hz. Peygamber'in Zeyneb bint Cahş'la evlilik kıssası gibi, Müslümanların sahih dinî inançlarını zedelemek gibi kötü niyetlerle İslam düşmanları tarafindan uydurulmuş rivayetlerdir. $^{21}$

Buraya kadar aktarılan görüşlere benzer şekilde İsmail Albayrak ve Özcan Hıdır gibi araştımacılar da İsrâiliyyât'ın kapsamına Yahudilerin dinî literatürleri ve efsanelerindeki unsurlar ile Hıristiyanlık, Zerdüştlük ve diğer Yakındoğu kültürlerindeki folklorik unsurların girdiğini, dolayısıyla İslam tefsir literatürüne giren tüm yabancı unsurların İsrâiliyyât kapsamında değerlendirilmesi gerektiğini belirtmişlerdir. ${ }^{22}$

İslam kaynaklarına giren birtakım yabancı bilgi ve haber malzemesinin İsrâiliyyât diye isimlendirilmesinde, Kur'an'ın nazil olduğu dönemin Arap yarımadasında Yahudi nüfusunun ve etkinliğinin fazla olması, Yahudilerle Müslümanların birçok kez karş1laşması, ticari ve kültürel alışverişin yoğunluğu, Yahudiliğin Hıristiyanlığa göre mütekaddim olması ve kültürel anlamda daha köklü temellere dayanması ve bilhassa nüzul döneminde ihtida eden birçok Yahudi kökenli insanın bulunması gibi sebeplere bağlanabilir. ${ }^{23}$

Bu bağlamda İsrâilî haberler çoğunlukla Yahudi haggadik (hukukî olmayan) bilgi ve rivayetleri, daha az oranda da halakhik (hukuki) ve pseudepigraphik

\footnotetext{
${ }^{21}$ Zehebî, el-ísrâiliyyât fi' 't-Tefsîr ve'l-Hadîs, s. 19-20.

${ }^{22}$ İsmail Albayrak, Qur'anic Narrative and Isra'iliyyat in Western Scholarship and in Classical Exegesis, The University of Leeds Deparment of Theology and Religious Studies, 2000, s. 121-122; Özcan Hıdır, Yahudi Kültürrü ve Hadisler, İnsan Yayınları, İstanbul 2006, s. 23.

${ }^{23}$ Zehebî, el-İ́srâiliyyât fi 't-Tefsîr ve'l-Hadîs, s. 21; Na'nâa, el-İsrâiliyyât ve Eseruhâ fì Kütübi't-Tefsîr, s. 73; Muhammed Ebû Şehbe, el-İsrâiliyyât ve'l-Mevzuât fî Kütübi't-Tefsîr, Kahire 1987, s. 12; Aydemir, Tefsirde İsrâiliyyat, s. 29-30.
} 
(mevzu/uydurma) rivayetlerden müteşekkil kabul edilir. ${ }^{24}$ Modern döneme ait bazı eserlerde İsrâiliyyât teriminin yanısıra Hıristiyan kültürüne ait haber ve rivayetler için mesîhiyyât veya nasrâniyyât gibi terimlere de yer verilmesi dikkat çekicidir. ${ }^{25}$ Fakat genel olarak yukarıda değindiğimiz sebeplerden dolayı "İsrâiliyyât" çok daha yaygın bir kullanıma sahiptir. Kaldı ki Müslüman âlimlerin ve Batılı araştırmacıların İsrâiliyyâtMesîhiyyât gibi bir ayrım gözettiklerini söylemek pek mümkün değildir.

İslam kaynaklarında İsrâiliyyât'la benzer anlamda kullanılan başka terimler de vardır. Hadis ve rivayet mecmualarının yanı sıra Müslüman müelliflerin klasik dönemlerde telif ettikleri genel tarih, din ve kültür tarihi, coğrafya, kozmogoni, kozmoloji, zooloji gibi alanlara ait eserlerde de İsrâiliyyât kapsamında değerlendirilen sayısız bilgi ve haber mevcuttur. $\mathrm{Bu}$ bağlamda fikıh ilminde dini bir delil olarak kullanılan şer'u men kablenâ, mutlak hakikat anlamında bütün dinlerde rastlanan hikmet veya ulûmu'l-evâil tabirleri ile ahbâr, kasas, el-kütüb, el-kütübü'l-kadîme, el-kütübü'ssâlife, kütübü'l-kussâs, sahâifü ehli'l-kitâb gibi kelimeler ve tabirler de kullanılmıștır. ${ }^{26}$

İsrâiliyyât esas itibariyle çok geniş kapsamlı bir kavramdır. Zira İsrâilî kaynaklı kabul edilen rivayet malzemesi genellikle İsrailoğullarına gönderilen peygamberleri, bu peygamberlerin günahkarlara yaptıkları uyarıları, bunlara verilen cezaları, zahidlerin söz ve davranışlarıyla onların mazhar olduğu manevi lütuflarla ilgili zengin bir muhtevaya sahiptir. Batılı bazı araştırmacılara göre ise İsrâiliyyât peygamberler, halifeler, idareciler, saltanatların çöküşü, mehdi inancı, kıyamet alametleri gibi fiten ve melâhimle ilgili hususları da içerir. ${ }^{27}$

Zehebî ve diğer müelliflerin eserlerindeki tanımlardan anlaşılmış olduğu gibi, İsrâiliyyât'ın kapsamına başta Yahudilik olmak üzere Hıristiyanlık, Mecûsilik gibi farklı din ve kültürlerden İslam kaynaklarına giren ve genellikle hurafe, efsane, esâtîr türünden olduğu kabul edilen haberlerin yanısıra münafıklar, zındıklar, oryantalistler ve

\footnotetext{
${ }^{24}$ Steven M. Wasserstrom, "Jewish Pseudepigrapha in Muslim Literature: A Bibliographical and Methodological Sketch", Tracing the Threads: Studies in the Vitality of Jewish Pseudepigrapha, ed. John C. Reeves, Atlanta 1994, s. 90.

${ }^{25}$ Ahmed Emîn, Fecrü'l-İslâm, Kahire trs., s. 161.

${ }^{26}$ Ebû Abdillah Şemsüddîn ez-Zehebî, Siyerü A'lâmi'n-Nübelâ, thk. Şuayb el-Arnaût ve dğr., Beyrut 1986, IV, 544-545; İbrahim Hatiboğlu, "İsrâiliyat", DİA İstanbul 2001, XXIII, 195.

${ }^{27}$ Hatiboğlu, "İsrâiliyat", DIAA, XXIII, 196.
} 
misyonerler gibi isimlendirmelerle anılan farklı çevrelerin İslam karşıtı söylemleri de dâhil edilmiştir. ${ }^{28}$ Keza tefsir kitaplarında Ahzâb 33/37. ayet münasebetiyle aktarılan, kimi müfessirlerce Hz. Dâvûd, iki hasım ve doksan dokuz koyun/kadın meselesiyle ilgili Sâd 38/21-25. ayetlerle irtibatlandırılan Hz. Peygamber ve Zeyneb bint Cahş izdivacına dair bazı rivayetler ${ }^{29}$ ile Garânik hadisesiyle ilgili haberler de İslam düşmanlarınca uydurulan, oryantalistler tarafından Hz. Peygamber ve Kur'an aleyhinde kullanılan İsrâilî haberler kabilindendir. ${ }^{30}$

\section{İsrâiliyyât'ın Terimleşme Süreci}

Klasik ve modern dönemlerde İslam âlimleri İsrâiliyyât'ın manası, kısımları, İslam'a uygun olup olmaması, İsrâiliyyât'ı kullanan kimseler ve onların kimlikleri, İsrâiliyyât nakletmenin hükmü, sahabe ve tâbiûnun İsrâilî haberler karşısındaki tavrı, İsrâiliyyât'ın tefsir ve hadis literatürüne girmesi ve benzeri konularla ilgilenmişlerdir. Bazı Batılı araştırmacılar ise daha ziyade İsrâiliyyât'ın arka planına atıfla İslam'ın otantisitesi ve başta Yahudilik kökeni olmak üzere Hıristiyanlık ve diğer dinlerin İslam ve Kur'an'ı Kerim üzerindeki etkileri gibi konularla meşgul olmuşlardır. ${ }^{31}$

Bazı araştırmacılara göre İsrâiliyyât kelimesinin geçtiği ilk kaynaklardan biri Vehb b. Münebbih'e (ö. 114/732) izafe edilen Kitâbü'l-İsrâiliyyât adlı eserdir. Kâtib Çelebi (ö. 1067/1657), Vehb b. Münebbih'in Kitâbü'l-İsrâiliyyât adlı bir eser sahibi olduğundan söz etmiş ve bu eserde kadim kültürlere ait haberlere yer verdiğine dikkat

\footnotetext{
${ }^{28}$ Mustafa Öztürk, Tefsirin Halleri, Ankara Okulu Yayınları, Ankara 2013, s. 167.

${ }^{29}$ Kurtubî, el-Câmi' li Ahkâmi'l-Kur'ân, XV, 116.

${ }^{30}$ Ebû Şehbe, el-İsrâiliyyât ve'l-Mevzuât fî Kütübi't-Tefsîr, s. 5, 323; Zehebî, el-İsrâiliyyât fi't-Tefsîr ve'lHadîs, s. 14. Daha geniş bilgi için bkz. Atilla Yargıcı, “Tefsirlerde İsrailiyyat Konusuna Eleştirel Bir Yaklaşım”, HÜİFD, cilt: 11, sayı: 15 (2006), s. 53-54.

${ }^{31}$ Abraham Geiger, Judaism and Islam, New York 1970; Bernard Lewis, The Jews of Islam, Israel Press Ltd, Tel Aviv 1977; Abraham Katsh, Judaism in Islam, State University of New York, Albany 1954; Abraham Katsh, Judaism and The Koran, A. S. Bernes and Co. Inc., New York 1962; Clair Tisdall, The Sources of Islam, Edinburg trs., Charles Torrey, The Jewish Foundation of Islam, Jewish Institude of Religion, New York 1933; Erwin Rosenthal, Judaism and Islam, London 1961; Richard Bell, The Origin of Islam in its Christian Environment, ed. Frank Cass, London 1968; Alfred Guillaume, The Influence of Judaism on Islam, The Legacy of Israel, ed. Erwin R. Bewan and Charles Singer, Oxford 1928; Joshua Finkel, Old Israelitish Tradition in The Koran, Proceedings of American Academy for Jewish Research, Philadephia 1930-1931.
} 
çekmiştir. $^{32} \mathrm{Bu}$ bilgi 1şığında, Vehb b. Münebbih'in hicri II. asrın başlarında yaşamış olduğu göz önüne alındığında İsrâiliyyât kelimesinin kullanımını tâbiûn dönemine kadar götürmek mümkündür. Ancak Khoury, İsrâiliyyât kelimesinin tarihi kaynaklarda Vehb b. Münebbih'le bağlantılı bir şekilde geçmediğini iddia etmiş, ayrıca Vehb'in Kitâbü'l-İsrâiliyyât adlı bir eser sahibi olduğuna dair sıhhatli bilgiler bulmanın zorluğuna dikkat çekmiştir. ${ }^{33}$ Meir Jacob Kister'e (ö. 2010) göre ise İsrâiliyyât'a dair derlenen ilk eser İbn İshak’1n (ö. 151/768) çağdaşı Hammad b. Seleme’nin (ö. 167/784) Ahbâru Ben̂̂ İsrâ̂̂l'idir. Fakat Kister bu esere dair pek bir bilgi vermemiştir. ${ }^{34}$ İsrâiliyyât kelimesinin ilk kullanımlarına dair bazı örneklerde görüleceği üzere, Vehb b. Münebbih'e atfedilen eser günümüze ulaşmamış olmakla birlikte, bazı İslam âlimleri tarafından bu eserin kullanıldığına ilişkin kayıtlar mevcuttur.

İsrâiliyyât teriminin ilk ortaya çıkışı Mes'ûdî’nin (ö. 345/956) Murûcu'z-Zeheb adlı eserindeki bir ibarenin kullanımında görülmektedir. ${ }^{35}$ Mes'ûdî atın yaratılması ile ilgili rivayetleri vermeden önce, bu ve buna benzer haberlerin İsrailoğulları'ndan gelen hikayelere dayandığını ifade etmiş, ${ }^{36}$ ardından atın yaratılmasıyla ilgili rivayetler bağlamında ilim ve dirayet ehlinin genel olarak haberleri hangi ölçütler dahilinde kabul ve reddettiklerine ilişkin bilgilere yer vermiş, daha sonra da nesnâs hadisi ${ }^{37}$ ve atın yaratılmasıyla ilgili merviyyatın ameli gerektiren, keza işitenlerin mutlaka doğru kabul etmesi gereken haberler kapsamında yer almadığını, bilakis gerçekliği mümkün haberler kapsamında İsrâilî haberler olarak görülmesi gerektiğini belirtmiştir. ${ }^{38}$

${ }^{32}$ Hacı Halife Mustafa b. Abdillah Kâtip Çelebi, Keşfü'z-Zünûn 'an Esâmi'l-Kütüb ve'l-Fünûn, nşr. Muallim Rifat-Şerafeddin Yaltkaya, İstanbul 1941, II, 1390; Na'nâa, el-İsrâiliyyât ve Eseruhâ fî Kütübi'tTefsîr, s. 185.

${ }^{33}$ Raif Georges Khoury, Wahb b. Munabbih der Heidelberger Papyrus PSR heid Arab 23: leben und werk des dichters, Otto Harrassowitz, Wiesbaden 1972, s. 247-254.

${ }^{34}$ Meir Jacob Kister, "The Sirah Literature", Arabic Literature to the End of The Umayyad Period, Cambridge University, Cambridge 1983, s. 354.

35 Roberto Tottoli, “İslamî Literatürde İsrâiliyyât Teriminin Kökeni ve Kullanımı”, trc. Mesut Kaya, Marife, y1l: 10; sayı: 2 (2010), s. 202.

${ }^{36}$ Ebü'l-Hasan Ali b. Hüseyin b. Ali Mes'ûdî, Murûcu'z-Zeheb ve Meâdinü'l-Cevher, ed. Charles Pellat, Beyrut 1970-1979, II, 370-371.

${ }^{37}$ Nesnâs hakkında daha geniş bilgi için bkz. İsmail b. Muhammed el-Aclûnî, Keşfü'l-Hafâ ve Müzîlü'lİlbâs, Dımeşk 2001, I, 474-475.

${ }^{38}$ Mes'ûdî, Murûcu'z-Zeheb ve Meâdinü'l-Cevher, II, 371-372. 
Denilebilir ki Mes'ûdî İsrâiliyyât kelimesini her ne kadar teknik bir terim olarak kullanmamış görünse de, İsrâilî haberlerin içeriği, bu haberlere karşı mesafeli tavrı dikkate alındığında "İsrâiliyyât" kapsamında değerlendirdiği haberlere karşı bir farkındalık ve duyarlılık oluşturmaya çalıştı̆̆ı açıktır. Dolayısıyla Mes'ûdî'nin Murûcu'z-Zeheb'indeki kullanım, İsrâiliyyât kelimesinin daha sonraki dönemlerde kazanacağı terimsel anlam için zemin teşkil edici bir ilk adım gibi değerlendirilebilir. ${ }^{39}$

Makdisî (ö. 355/966) de İsrâilî haberler ve rivayetler karşısında mesafeli bir tavır takınmış ve bu tavrıyla çağdaşı Mes'ûdî ile benzer bir çizgide yer almıştır. Mesela yeryüzünün yaratılışıyla ilgili hikâyeler bağlamında Makdisî, Müslüman kıssacılara ait kitaplarda çok sayıda problemli anlatının bulunduğunu söylemiş, Vehb b. Münebbih’in Hz. İsa'ya atfettiği bir rivayetle ilgili olarak da, "Bunlar avâm-1 nâsın sevdiği kıssalardır. Şayet bunlar Ehl-i kitabın uydurması veya kıssacıların tezviratı kabilinden

\footnotetext{
39 “Sahabe döneminde, Yahudilik veya Hıristiyanlıktan İslam’ı seçen din bilginlerinin söyledikleri veya birtakım kitaplardan naklettikleri bilgi ve haberler Müslümanların dikkatini çekmiştir. Bunun nedeni, bu tür kaynakların geçmiş peygamberler, gelecekle ilgili haberler, kıyamet alametleri, cennet-cehennem gibi halkın hemen hemen her zaman merak ettikleri konularla ilgili esrarengiz, abartılı ve detaylı birtakım bilgiler içermesiydi. Abdullah b. Selâm (ö. 43/663), Abdullah b. Amr b. As (ö. 65/674), Selmân el-Fârisî (ö. 34/656), Ebü'l-Celd el-Cevnî (ö. ?), Übey b. Ka’b (ö. 19/640) ve Temîm ed-Dârî (ö. 40/661) gibi bazı sahâbîler sadece mühtedi din adamlarından duydukları haberlerle yetinmemiş, Ehl-i kitaptan birtakım kitaplar okumuş ve bu kitaplardan nakilde bulunmuşlardır. Tevrat ve İncil adıyla bilinen kutsal kitaplara karşl1ık gelen el-kütüb, sahabe döneminde, eskiye nazaran daha detaylı bilinmeye başlanan ve onlardan nakillerde bulunulan kitaplar haline dönüşmüş, anlam yönünden genişlemiştir. Tâbiûn döneminden itibaren el-kütüb kavramının anlamı daha da genişlemiş, Tevrat ve İncil, bu iki kitaba dahil edilen metinler, apokrifler, bu kitaplar üzerine yapılmış tefsir çalışmaları, farklı kültürlere ait edebî ve ahlakî eserler, göklerin, yerin, karaların, denizlerin ve muhtelif varlıkların yaratılışını, tuhaf özelliklerini anlatan "acâî" türü kitaplar bu kavramın kapsamı alanine girmiştir. Tarihsel süreçte bu kitaplardan yapılan nakiller, karşıt bir hareketi de beraberinde getirdi. Ehl-i kitabın kitaplarına karşı sahabe döneminden itibaren başlayan muhalefet etkisini gittikçe artırdı. Hicri IV. asırdan itibaren el-kütüb kavramı, yerini yavaş yavaş İsrâiliyyât kavramına bırakmıştır." İslam literatürünün ilk kaynaklarında sıkça tekrarlanan "el-Kütüb/Kitaplar" kavramının anlamı, bu kavramın İslam öncesi dönemden hicri IV. asrın sonlarına kadar olan dönemdeki gelişimi ve "İsrâiliyyât" kavramıyla yer değişimi hakkında farklı bir yaklaşım için bkz. Ali Kuzudişli, “el-Kütüb’ten İsrailiyat’a Bir Kavramın Tarih İçindeki Yolculuğu”, CÜİFD, cilt: 16, sayı: 1 (2012), s. 131-164.
} 
olmayıp gerçekten sahihse, tümüyle temsil ve teşbih türündedir." demiş; ancak söz konusu rivayetleri tanımlamada "İsrâiliyyât" kelimesini zikretmemiştir. ${ }^{40}$

İsrâiliyyât kelimesini kullanan âlimlerden birisi de İbnü'l-Muraccâ'dır. Vefat tarihi bilinmeyen İbnü'l-Muraccâ yaklaşık 430/1040'lu yıllarda Kudüs, Halilürrahman ve Şam'ın faziletleriyle ilgili birtakım rivayetleri topladığg Fedâilü Beyti'l-Makdis ve'lHalîl ve Fedâilü 'ş-Şâm adlı eserinde Hz. Süleyman'ın çocuklarıyla ilgili bir rivayeti ele alıp isnad zincirindeki râvileri zikrederken, "Bu râviler bize Vehb b. Münebbih'ten gelen İsrâiliyyât’tan rivayette bulunmuşlardır.” ifadesine yer vermiştir. ${ }^{41}$

Tarihî süreçte İsrâiliyyât kelimesini kullanan âlimlerden bir diğeri de Gazâlî’dir (ö. 505/1111). Gazâlî, İhyâu Ulûmi'd-Dîn adlı eserinde râvisini zikretmeksizin birtakım rivayetlere yer vermiştir. Hikmet konusunda üç yüz altmış kitap yazmış ve hekim olmaya hak kazanmış bir kimse hakkında Allah'ın, o dönemin peygamberine bu hekimin yazdıklarının kendi rızasını kazanamadığını ve bir arpa boyu yol kat edemediğini bildirmesi üzerine hekimin pişman olarak yazma işini terk edip halka karışarak Allah'ın rızasını kazanmaya çalışmasını, ${ }^{42}$ başka bir yerde ise bir peygamberin, uzun seneler ibadete daldıktan sonra tevbesinin kabul olunmasina dair herhangi bir işaret görmeyen bir kulun tevbesini kabul etmesi hususunda Allah'a niyazda bulunmasını, ${ }^{43}$ bir diğer yerde ise bir adamın başka bir beldeden bir kadınla evlenmesi ve onu getirmesi için kölesini göndermesi üzerine kadının yolda köleye zina teklifinde bulunmasını, kölenin ise kadınla mücadele ederek kendini korumasını ve bunun üzerine Allah'ın o köleyi takvası sebebiyle İsrailoğullarına peygamber yapmasını ${ }^{44}$ anlatan haberlerin hepsinde Gazâlî bu rivayetlerin "İsrâiliyyât"ta geçtiğini ifade etmiştir.

Bütün bu rivayetlerin aktarımında Gazâlî, fi'l-isrâiliyyât, ruviye fi'l-isrâiliyyât, zekera ba'du'l-ulemâ fi'l-isrâiliyyât gibi ifadelere yer vermiş; ${ }^{45}$ fakat bu ifadelerle

\footnotetext{
${ }^{40}$ Ebû Nasr Mutahhar b. Tâhir el-Makdisî, el-Bed've't-Târîh, Bağdat trs., II, 47, 50.

${ }^{41}$ Tottoli, “İslamî Literatürde İsrâiliyyât Teriminin Kökeni ve Kullanımı”, s. 203.

${ }^{42}$ Ebû Hamid Muhammed b. Muhammed Gazâlî, Ihyâu Ulûmi'd-Dîn, Endenozya trs., I, 71.

${ }^{43}$ Gazâlî, Ihyâu Ulûmi'd-Dîn, IV, 34.

${ }^{44}$ Gazâlî, İhyâu Ulûmi'd-Dîn, IV, 52.

${ }^{45}$ Gazâlî, Ihyâu Ulûmi'd-Dîn, IV, 34, 52, 277, 336, 352, 365.
} 
teknik bir terim olarak İsrâiliyyât hakkında müspet-menfi bir değerlendirme yapmaktan öte, bir rivayet türüne ve bunun menşeine işaret etmiştir.

Gazâlî ile aynı çağda yaşayan Ebû Bekr Muhammed b. Velîd et-Turtûşî (ö. 520/1126) de eserlerinde İsrâiliyyât kelimesine yer vermiştir. Şöyle ki Turtûşî Sirâcü'lMülûk adlı eserinde İsrâiliyyât kelimesini tespit edebildiğimiz kadarıyla ruviye fi'lisrâiliyyât ve fi'l-isrâiliyyât gibi ifadelerle bir rivayet türünü ifade eder bağlamda kullanmış, ${ }^{46}$ bunun yanında ve-min a'cebi mâ ruviye fi'l-isrâiliyyât ifadesinde olduğu gibi bu rivayet malzemesinde tuhaf/garip karşılanan hususları vurgulamıştır. Çok belirgin olmamakla birlikte bu vurgu İsrâiliyyât malzemesine ihtiyatla yaklaşılması gerektiğini ima etmektedir. ${ }^{47}$

İsrâiliyyât hakkında çok belirgin denebilecek mesafeli tavır Ebû Bekir İbnü'lArabî'nin (ö. 543/1148) Ahkâmu'l-Kur'ân adlı eserinde karşımıza çıkmaktadır. İbnü'lArabî, Hz. İbrahim'in tek başına yemek yememesi, yemeği hazır olunca sofrasına birilerini davet etmesi ve günlerden birgün kendisiyle beraber oturan adamla sohbet etmesi $^{48}$, bir başka yerde Hz. Musa'nın kendisine hiçbir şey söylenmeksizin Firavun'un kapısında beklemesi ve Firavun birgün dışarı çıkarken Hz. Musa ile karşılaşıncaya kadar kimsenin ona bir şey sormaması, ${ }^{49}$ bir başka rivayette ise bir adamın ayakta namaz kılarken bir gözüyle geçmekte olan kadına bakması üzerine başını yere eğerek yerdeki çubuğu alarak kadına bakan gözünü oyması ${ }^{50}$ ve yine bir başka rivayette de Hz. İsa'nın bir domuzla karşılaşması ve domuz kendisine karşılık veremeyeceği halde ona selam vermesi ${ }^{51}$ şeklindeki haberleri "İsrâiliyyât'ta geçtiği üzere" gibi ifadeler kullanarak nakletmiştir.

Birçok kez ruviye fi'l-isrâiliyyât, fi'l-isrâiliyyât gibi ifadeler kullanan İbnü'lArabî $^{52}$ Enbiyâ 21/77-78. ayetlerin tefsirinde, Allah'ın Kur'an'da zikrettiği geçmiş ümmetler, peygamberler, onların sözleri ve fiilleriyle ilgili ifadelerin en güzel ve en

\footnotetext{
${ }^{46}$ Ebû Bekr Muhammed Turtuşî, Sirâcü’l-Mülûk, Kahire 1994, s. 69, 715.

${ }^{47}$ Turtuşî, Sirâcü'l-Mülûk, s. 715.

${ }^{48}$ Ebû Bekr Muhammed İbnü'l-Arabî, Ahkâmu'l-Kur'ân, Beyrut 2003, II, 20.

49 İbnü'l-Arabî, Ahkâmu'l-Kur'ân, III, 259.

50 İbnü'l-Arabî, Ahkâmu'l-Kur'ân, III, 379.

${ }^{51}$ İbnü'l-Arabî, Ahkâmu'l-Kur'ân, III, 451.

52 İbnü'l-Arabî, Ahkâmü'l-Kur'ân, III, 40, 249.
} 
doğru anlatımlar olduğunu söylemiş, ardından “Bu kıssalar İsrâiliyyât'ta değiştirilmiş bir şekilde anlatılmış, asılsız eklemeler ya da asıl maksadı bozacak çıkarmalar yapılarak aktarılmıştır.” şeklindeki normatif cümleleri eklemiştir. Ayrıca, Kasas 28/27-28. ayetler münasebetiyle rızası alınmadan kız çocuğunun evlendirilip evlendirilmeyeceği hususunda İmam Mâlik'in (ö. 179/795) görüşünü aktaran İbnü’l-Arabî kendi mezhep imamının bu ayetlerle ihticac/istidlal tarzıyla ilgili olarak "Bu ayetle ihticacı, İmam Mâlik'in İsrâiliyyât'a güvendiğini/esas aldığını gösterir." demekle, ${ }^{53}$ aslında bu malzemeye peşin güvenilirlik atfetmemek gerektiğini de ifade etmiştir. Buna göre İsrâiliyyât genel olarak problemli yahut en azından mevsukiyeti ispata muhtaç bir bilgi ve rivayet türüdür. Bu yüzden, Enbiyâ 21/77-78. ayetlerle ilgili aktarılan İsrâiliyât'ta olduğu gibi, diğer bütün İsrâiliyyât malzemesinde de Kur'an'ın zahirine uygun düşenler sahih, ters düşenler batıl, doğru ya da yanlış olduğunu tespit hususunda Kur'an'da açık beyan/hüküm bulunmayan rivayetler ise her iki ihtimale de açık kabul edilmelidir. ${ }^{54}$

İsrâilî rivayetleri ciddi anlamda eleştiriye tâbi tutan İbn Atıyye'nin (ö. 541/1147) el-Muharrerü'l-Vecîz adlı eserinde İsrâiliyyât terimine yer vermemiş olması da oldukça önemlidir. "Kütübü Benî İsrâîl”, “İsrailoğulları'nın kitaplarından alınmıştır, bu sebeple bu rivayeti/haberi zayıf buldum”, “Zannediyorum bu İsrailoğulları'nın kitaplarından alınmıştır" şeklindeki ifadelerle rivayetin/haberin kaynağına dikkat çektiği görülmektedir. $^{55}$ Kanaatimizce İbn Atıyye'nin İsrâilî rivayetlere karşı bu kullanımlarından, İsrâiliyyât kelimesinin bu dönemde henüz yaygın ve meşhur bir terim olarak kullanılmadığı ve farklı terim veya terkiplerle söz konusu bilgi türünün ifade edildiği şeklinde bir sonuca ulaşmak mümkündür. ${ }^{56}$

Klasik dönemlerde İsrâiliyyât'ın menfi anlam içeriğiyle kullanıldığı bir diğer kaynak İbnü'l-Cevzî'nin (ö. 597/1200) Kitâbü'l-Kussâs ve'l-Müzekkirîn adlı eseridir. İbnü'l-Cevzî İsrâiliyyât kelimesini selefin kıssacılıktan hoşlanmadıklarına dair

\footnotetext{
53 İbnü'l-Arabî, Ahkâmü'l-Kur'ân, III, 506.

54 İbnü'l-Arabî, Ahkâmü'l-Kur'ân, III, 265.

55 Ebû Muhammed Abdülhak b. Galib İbn Atıyye, el-Muharrerü'l-Vecîz fî Tefsîri Kitâballâhi'l-Azîz, Beyrut 1422, II, 445; III, 221.

56 Mesut Kaya, Çă̆daş Tefsirlerde İsrâiliyata Yaklaşım ve Kitab-ı Mukaddes Bilgilerinin Kullanımı, (Yayımlanmamış Doktora Tezi), NEÜSBE, Konya 2013, s. 69-70.
} 
rivayetleri ele alırken kullanmıştır. ${ }^{57} \mathrm{~Hz}$. Ömer'in Tevrat'tan bazı parçaları Hz. Peygamber'e getirmesi üzerine Peygamber, "Kurtar kendini bunlardan Ömer!” demiştir ki İbnü'l-Cevzî'ye göre İsrâiliyyât'tan olup gayr-i makul görünen haberler arasında sahih olanlar nadirdir. ${ }^{58}$

Necmeddîn et-Tûfî ise (ö. 716/1316) el-İksîr fî̀ İmi't-Tefsîr adlı eserinde İsrâiliyyât terimini kullanmış ve oldukça önemli bilgilere yer vermiştir:

Biz biliyoruz ki müfessirler bir kelime veya bir ayet hakkında onlarca farklı görüş belirtmek suretiyle ihtilafa düşmüşlerdir. Bu görüşlerin kimi zaman birbiriyle çatışır ve birbirini çürütür nitelikte olduğu vakidir. Tefsirdeki bu ihtilafların sebebi şudur: Bazı sahâbîler Hz. Peygamber'den Kur'an tefsirine dair bilgiler almış ve bu bilgileri imkânlar nispetinde birbirleriyle paylaşmışlardır. İhtimal ki bazı sahâbîler kısa bir süre içerisinde vefat emiş ve bu yüzden sahip olduğu tefsir bilgisi kendisiyle birlikte toprağa gitmiştir. Ayrıca sahâbîler Hz. Peygamber'in vefatından sonra çeşitli bölgelere gitmiş ve tefsirle ilgili bilgilerini tâbilerine nakletmişlerdir. Ancak her sahâbî Kur'an'ın tefsirine bütünüyle vakıf değildir. Dahası, kısmî tefsir bilgisine sahiptir. Hz. Peygamber hayatta iken Kur'an'ın bütünü hakkında tefsir donanımına sahip sahâbî sayısı oldukça azdır. Kur'an tefsiri hakkında kısmî bilgi ve donanım sahibi olan bir sahâbî bilgi birikimini kendi tâbisine aktarmış, ancak bu tâbî muhtemelen tefsirle ilgili eksiğini tamamlayacak bir başka sahâbîyle karşılaşamamış veya karşılaşsa bile o sahâbîde fazladan bir bilgiye ulaşamamış, dolayısıyla, tefsir bilgisi kendisine hocalık yapan o tek sahâbîden öğrendikleriyle sınırlı kalmıştır. $\mathrm{Bu}$ yüzden, ister istemez tefsir bilgisini ikmal için kâh kendi içtihadına, kâh dilbilimsel çıkarıma, kâh sünnete, kâh tefsire konu olan ayetle benzer içerikli başka bir ayete başvurmuştur. Bütün bunların dişında, tefsir alanında kaynak olarak kullanıma elverişli gördüğü tarih, geçmiş milletlere ait önemli

\footnotetext{
${ }^{57}$ Tottoli, “İslamî Literatürde İsrâiliyyât Teriminin Kökeni ve Kullanımı”, s. 205.

${ }^{58}$ Roberto Tottoli'nin Hz. Ömer'in Tevrat'tan bazı parçaları Hz. Peygamber'e getirmesi üzerine Hz. Peygamber'in, "Kurtar kendini bunlardan Ömer!” ifadesinden sonra gelen “Özellikle de İsrâiliyyât'ta mevcut olan anlamsız şeylerden” şeklindeki İbnü’l-Cevzî’ye ait olan cümleyi hadisin bir parçası olarak zannettiği anlaşılmaktadır. İbnü’l-Cevzî ilgili paragrafta, “Öncekilerin haberlerine ilişkin kıssalar nadiren sahihtir. Özellikle de İsrâiliyyât’tan gelen..." ifadelerine yer vermiş, bununla birlikte, "Özellikle de İsrâiliyyât'tan olup da gayrı makul olduğu bilinen şeyler (nadiren sahihtir)" diyerek sözlerine açıklık getirmiştir. Bkz. Tottoli, "İslamî Literatürde İsrâiliyyât Teriminin Kökeni ve Kullanımı", s. 205 (Çevirenin notu).
} 
olaylar ve İsrâiliyyât malzemesinden de faydalanmıştır. İşte bu suretle tefsirin kapsamı alabildiğine genişlemiş ve onun kapsamına çok farklı şeyler girmiştir. ${ }^{59}$

Görebildiğimiz kadarıyla İsrâiliyyât ilk kez bir tefsir usulü kitabında hem terim olarak zikredilmiş, hem de sahâbî ve tâbiûn dönemi tefsir anlayışının önemli unsurlarından biri olarak kullanılmıştır.

Bütün bu kaynaklardaki veriler 1şı̆̆ında İsrâiliyyât kelimesinin menfi manada terimleşmesinde Ebû Bekr İbnü'l-Arabî'nin önemli bir adım attığı söylenebilir. ${ }^{60}$ Şarkiyatçıların bir kısmı Hasan Basrî’den (ö. 110/728), Malik b. Dînâr'dan (ö. 131/748) nakledilen İsrâilî bilgilerin varlığından hareketle terimi II/VIII. yüzyılın başlarına kadar götürmüş olsalar da, bu tespit kelimenin terimleşme süreci hakkında sağlıklı bilgi içermemektedir. $^{61}$

\section{Erken Dönemlerde İsrâiliyyât Telakkisi}

İslam'ın erken dönemlerinde İsrâiliyyât daha ziyade Ehl-i kitap kökenli bilgiler ve haberlerin kaynağını belirten, dolayısıyla müspet ya da menfi manada değer içermeyen bir kelime olarak kullanılırken, özellikle Ehl-i hadis çizgisini sistematik Selefiliğe dönüştüren İbn Teymiyye ve talebesi İbn Kesîr tarafından olumsuz çağrışımlara sahip bir terim haline gelmiştir.

Esasen sahabe, tâbiûn, tebe-i tâbiîn kuşaklarında İsrâiliyyât Kur'an tefsirinin tabiri caizse bir parçası gibi algılanmış ve bilhassa kıssalar bağlamında sıkça kullanılmıştır. Tefsire dair görüşleri günümüze ulaşan ilk üç nesildeki âlimler arasında İsrâiliyyât'la ilişkisi açısından öncelikle Abdullah b. Abbas (ö. 68/687) ile Ebû Hüreyre (ö. 58/677) zikredilir ve bu iki sahâbîye Abdullah b. Amr b. el-Âs (ö. 65/674), Abdullah b. Selâm (ö. 43/663), Temîm ed-Dârî (ö. 40/661) gibi isimler eklenir. Tâbiûn neslinden Ka'b elAhbâr (ö. 32/652) ve Vehb b. Münebbih (ö. 114/732), tebe-i tâbiînden ise Kelbî (ö.

\footnotetext{
${ }^{59}$ Ebü’r-Rebî' Necmüddîn Süleymân et-Tûfî, el-ìksîr fỉ Illmi' 't-Tefsîr, nşr. thk. Abdulkâdir Hüseyn, Kahire trs., s. 36 .

${ }^{60}$ Albayrak, Qur'anic Narrative and Isra'iliyyat in Western Scholarship and in Classical Exegesis, s. 134.

${ }^{61}$ Hatiboğlu, "İsrâiliyat”, DİA, XXIII, 195.
} 
146/763), İbn Cüreyc (ö. 150/767), Mukâtil b. Süleyman (ö. 150/767) ve İbn İshâk (ö. 151/768) gibi isimler zikredilir. ${ }^{62}$

İlk Müslüman nesillerin Kur'an tefsirinde naklettikleri İsrâiliyyât daha ziyade geçmiş peygamberler ve ümmetler ile kâinatın ve insanın yaratılışı, Âdem ve eşinin cennetteki hayatları, Âdem-Havva-İblis üçlüsünün yaşadıkları, cennetten kovulup yeryüzüne düşüşleri, Kâbe'nin inşası, Nuh'un gemisi ve tufan hadisesi, Hârût-Mârût, Tâlût-Câlût, Tâbût-Sekîne gibi çeşitli konularla ilgilidir. Bütün bu konularla ilgili rivayetler arasında gerek klasik dönem Sünnî kelamî sistemindeki Allah tasavvuruna, gerek ismet-i enbiya fikrine ters düşen birçok husus bulunmakta, yine bu rivayetlerde çağdaş aklın hurafe olarak değerlendirdiği anlatımlar da çok önemli bir yer tutmaktadır. Örnek vermek gerekirse, haberî sıfatlar ile arş ve kürsî gibi kavramlarla ilgili muhtelif ayetlerin tefsirine dair rivayetlerde Allah müşahhas bir varlık gibi betimlenmiş, Yûsuf 13/24. ayetteki ve-hemme bihâ ifadesi ise İbn Abbas, Mücahid, Saîd b. Cübeyr gibi sahâbî ve tâbiî âlimlerce çok ilginç şekilde izah edilmiştir. ${ }^{63}$ Öte yandan, müteahhir dönem Ehl-i sünnet kelamındaki ismet-i enbiya fikriyle bağdaşmaz nitelikteki İsrâilî rivayetler Hz. Dâvûd, iki hasım, doksan dokuz koyun/kadın meselesi ve Hz. Süleyman'ın tahtının üzerine ceset bırakılması gibi konularla ilgili ayetlerin tefsirinde de zikredilmiştir.

Sahabe, tabiûn ve tebe-i tâbiînin Kur'an tefsirinde İsrâiliyyât'1 kullanması, hem erken dönem İslam ilim ve kültür geleneğinin diğer din ve kültürlerle ilişkisine hem de bu dönemdeki Müslümanların Ehl-i kitap algısına 1şık tutması bakımından önemlidir. İsrâiliyyât konusundaki rahat tavırdan anlaşıldığı kadarıyla erken dönem İslam âlimleri tefsirde başka din ve kültürlere ait bilgilerin kullanılmasında sakınca görmemişlerdir. Burada ciddi bir özgüven söz konusudur ve bu özgüvenin oluşumunda Bakara 2/211, Yunus 10/94, Nahl 16/43, İsrâ 17/101, Enbiya 21/7. ayetlerde Ehl-i kitabı̀n referans gösterilmesi, ayrıca Bakara 2/41, 91, 97; Âl-i İmrân 3/3; Nisa 4/47; Mâide 5/46, 48 gibi

\footnotetext{
${ }^{62}$ Zehebî, el-İsrâiliyyât fi't-Tefsîr ve'l-Hadîs, s. 55-93; Na'nâa, el-İsrâiliyyât ve Eseruhâ fî Kütübi'tTefsîr, s. 123-197.

${ }^{63}$ Ebû İshâk Ahmed es-Sa'lebî, el-Keşf ve'l-Beyân, Beyrut 2004, III, 364; Kurtubî, el-Câmi' li Ahkâmi 'lKur'ân, IX, 110.
} 
ayetlerde Kur'an'ın kendinden önceki kitaplarla ilgili olarak “musaddık" diye nitelendirilmesi de kuşkusuz etkili olmuştur. ${ }^{64}$

Nahl 16/43 ve Enbiya 21/7. ayetlerdeki, "Eğer bilmiyorsanız zikir ehline sorun" ifadesi klasik tefsirlerde ağırlıklı olarak, "Ey müşrikler! Öteden beri melek değil, beşer peygamber gönderme sünnetimizi bilmiyorsanız, gidin bu gerçeği Ehl-i kitaba sorun.” şeklinde anlaşılmıştır. ${ }^{65} \mathrm{Bu}$ ayetlerdeki mana ve mesaj, temelde müşriklerin $\mathrm{Hz}$. Peygamber'in beşer olmasına yönelik sözde itirazlarına cevap mahiyetinde olmakla birlikte, Ehl-i kitabı bir referans mercii gibi konumlandırma stratejisine de atıfta bulunur. Mekke döneminde müşriklerin giderek güç ve yaygınlık kazanan itirazlarına karşı Ehl-i kitapla ittifak kurma veya kendilerinden destek alma stratejisine işaret eden ayetler de mevcuttur. Mesela, Müddessir 74/31. ayette mealen şöyle buyrulur: "Biz cehennemde bekçi olarak sırf melekleri görevlendirdik ve onların sayısını, ["Biz çok kalabalığız; on dokuz meleğin hakkından geliriz." diye alay eden] o kâfirler/müşrikler için sınama/yanılma vesilesi kıldık ki böylelikle hem geçmişte vahye mazhar kılınanların [Yahudilerin] bilgileri sağlamlaşsın, hem de müminlerin imanları artsın [istedik]. Bu sayede Yahudiler ile müminler/müslümanlar şüpheye düşmezler. Peygamber'e ve Kur'an'a inanma hususunda akılları karışık olanlar ile kâfirlikte karar kılanlar ise, 'Allah'ın böyle bir misal vermesinin ne anlamı var!' diye söylenirler.”

Rivayetlere göre ticaret için Mekke'ye gelip giden Yahudiler bazı Müslümanlara cehennemdeki bekçi meleklerin sayısını Hz. Peygamber'in bilip bilmediğini sormuşlar (Müddessir suresinin 30. ayeti bunun üzerine nazil olmuştur). Hz. Peygamber cehennem bekçilerinin sayısının ondokuz olduğunu söyleyince, bunun kendi kaynaklarındaki bilgiyle örtüştüğünü görmüş ve Kur'an'ın Allah katından geldiğine kani olmuşlardır. Bununla birlikte kendi dinlerini de terk etmemişlerdir. Bu arada müşrikler Yahudilerin Kur'an'daki bilgileri yalanlamalarını beklemişler, fakat bu beklentileri boşa çıkmıştır. Ebû Cehil gibi bazı müşrikler ise cehennemde ondokuz bekçi melek bulunduğunu

\footnotetext{
${ }^{64}$ Daha geniş bilgi için bkz. Mustafa Öztürk, "İslam Tefsir Geleneğinde Ehl-i Kitapla İlgili Bazı Telakkilerin Epistemik Değeri”, Kur'an’ın Farklı İnanç Mensuplarına Yaklaşımı, Sempozyum, Mayıs 2007, s. 47-49.

${ }^{65}$ Taberî, Câmiü'l-Beyân fỉ Tefsîri' 'l-Kur'ân, VII, 586-587.
} 
bildiren ayetle ilgili olarak, "Biz sayıca çok kalabalığız; onların hakkından geliriz." diye alay etmişlerdir. ${ }^{66}$

Fahreddîn er-Râzî (ö. 606/1210), “Cehennemde ondokuz bekçi meleğin görevlendirildiğini haber veren bu müteşabih ayetin Ehl-i kitabın yakîn sahibi olmasında nasıl bir rol oynadığı meselesiyle ilgili olarak, "Otuzuncu ayetteki bilgi, Ehl-i kitabın kutsal kitaplarında da mevcuttu. Rasûlullah bu konuyla ilgili olarak önceden tahsil ve tedris edilmiş bir bilgi olmaksızın Ehl-i kitap kaynaklarına muvafik bildirimde bulundu. Böylece Rasûlullah'ın ancak semavi vahiy sayesinde bu bildirimde bulunduğu ortaya çıktı ve Rasûlullah'a inanan kitâbîlerin imanı arttı." diye izah etmiştir. ${ }^{67}$

Bütün bu rivayetler sahabe ve tâbiûn nesli ile Ehl-i kitap arasında dinî bilgi alışverişinin bulunduğunu, kitâbîlerden bilgi almanın sakıncalı bir durum olarak algılanmadığını gösterir. Bunu destekleyen bir diğer delil de, Hz. Peygamber'e

\footnotetext{
${ }^{66}$ Bkz. Ebu'l-Fidâ İmâdüddîn İsmâil b. Ömer İbn Kesîr, Tefsîru'l-Kur'âni'l-Azîm, thk. Mustafa es-Seyyid Muhammed vd., Kahire 2000, IV, 444.

${ }^{67}$ Ebû Abdillah Muhammed b. Ömer Fahreddîn er-Râzî, et-Tefsîru'l-Kebîr, Beyrut 2004, XXX, 181.
} Müddessir 74/30. ayetle ilgili olarak Tirmizî’nin (ö. 279/892) Câbir b. Abdillah’tan (ö. 78/697) naklettiği bir hadiste de şu ifadelere yer verilmiştir: "Kimi Yahudiler Rasûlullah'ın ashabından bazı kimselere, "Sizin peygamberiniz cehennem bekçilerinin sayısını biliyor mu?” diye sordular. Sahâbîler, “Peygamberimize sormadan bir şey söyleyemeyiz.” diye karşılık verdiler. Derken bir adam Rasûlullah’ın yanına gelip, "Muhammed! Bugün senin arkadaşların [Yahudiler] karşısında yenik düştü.” dedi. Rasûlullah, "Nasıl ve ne sebepten yenik düştüler?" diye sordu. Adam, "Yahudiler onlara sizin peygamberiniz cehennem bekçilerinin sayısını biliyor mu?' diye sordu” deyince Rasûlullah, "Peki bizimkiler ne cevap verdi?" buyurdu. Adam, "Senin arkadaşların, 'Peygamberimize sormadan bir şey söyleyemeyiz!' diye karşılık verdiler.” dedi. Bunun üzerine Peygamber, "Bilgi sahibi olmadıkları bir konu hakkında kendilerine soru sorulunca, 'Peygamberimize danışmadan bir şey diyemeyiz.' diyen kimseler [soru sahibi Yahudiler karşısında] yenik düşmüş sayılır mı? Kaldı ki o Yahudiler [vakti zamanında] kendi peygamberlerinden olmadık isteklerde bulunmuş, Hz. Musa’ya “Apaçık biçimde Allah’ı bize göster.” demişlerdir. Allah’ın düşmanı o Yahudileri bana çağırın ki ben de onlara cennetteki toprağın -“dermek” denilen o toprak yumuşak, pürüzsüz, adeta un gibidir- nasıllığı hakkında sorayım.” buyurdu. Yahudiler gelince, “Ey Ebü'l-Kâsım! Cehennemdeki bekçilerin sayısı kaçtır?” diye sordular. Rasûlullah, "Şu kadar sayıdadır." dedi ve ilkin on, ardından dokuz rakamına işaret etti. Yahudiler, "Evet, doğru!" dediler. Bu defa Rasûlullah, "Peki, şimdi siz söyleyin bakalım, cennet toprağı [dermek] nasıl bir şeydir?" diye sordu. Onlar bir an susup kaldılar; ardından, "Ey Ebü'l-Kâsım! Bir nevi ekmeklik un gibidir." diye cevapladılar. Bunun üzerine Rasûlullah, "Ekmek de zaten [dermek gibi] undan yapılır." dedi. Tirmizî, Tefsir, 70 . 
atfedilen, "İsrâiloğullarından nakilde bulunmanızda sakınca yoktur." rivayetidir. ${ }^{68}$ Bununla birlikte, İsrâiliyyât konusunda olumsuz bakış açısının giderek güçlendiği müteahhir dönemlerde bu rivayetten ziyade, "Ehl-i kitabın size naklettiği bilgileri ne tasdik ne tekzip edin." mealindeki rivayet esas alınmıştır. ${ }^{69}$

Gözden kaçırılma ihtimaline karşı bir kez daha belirtelim ki erken dönem İslam tefsir geleneğinde İsrâiliyyât'ın kendine yer edinmesinde İslam'ın itikat, ahlak ve hukuk alanlarında Yahudilik ve Hıristiyanlıktan çok daha mükemmel bir nizama sahip olduğu inancına dayalı özgüven ve bununla çok yakından ilgili olarak özellikle Mekkî ayetlerde Ehl-i kitaba müspet atıflarda bulunulması çok önemli bir rol oynamıştır. Mekke dönemindeki şartlar dikkate alındığında, Müslümanlar ile Ehl-i kitap arasında görece yakınlığın bulunduğu, hatta Ehl-i kitaba olumlu atıfların Müslümanlarda az çok destek hissi uyandırdığı tespitinde bulunabilir. Medine döneminde Yahudilerle ilişkilerin gerginleşmesine koşut olarak, Kur'an'ın dil ve üslubunda Ehl-i kitapla ilgili olarak giderek sertleşme ve ötekileşmeye yönelik bir tutum söz konusu olsa da ilk nesil Müslümanlar zaman, mekân, tarihsel ve toplumsal şartlardan bağımsız olan temel dinîahlakî değerler ve hakikatlerin Ehl-i kitaba ait dinî metinlerde yer aldığını öğrenip bunları kendi kültürlerinde paylaşmaktan rahatsızlık duymamışlardır. İsrâiliyyât naklinin caiz olup olmadığıla ilgili muhtelif hadis rivayetleri ${ }^{70}$ muhteva açısından değerlendirildiğinde, Kur'an'ın nazil olduğu vasattaki toplumsal ve kültürel vakıaya uygunluk noktasında, "İsrâiloğullarından rivayette bulunmanızda sakınca yoktur.",71 rivayetinin tercihe şayan olduğu hükmüne varılabilir. ${ }^{72}$

\footnotetext{
${ }^{68}$ Buhârî, Enbiya, 50; Ebû Abdillah Ahmed İbn Hanbel, el-Müsned, Beyrut trs., II, 159, 202.

${ }^{69}$ Buhârî, I’tisâm, 25.

${ }^{70}$ Bir rivayette Hz. Peygamber'in, "İsrâiloğullarından nakilde bulunmanızda sakınca yoktur." (Buhârî, Enbiyâ, 50; Tirmizî, İlim, 11) ifadesi yer alır. İkinci bir rivayette, "Ehl-i kitaba herhangi bir konuda soru sorup bilgi talebinde bulunmayın. Zira ihtimal ki onlar size doğru bir bilgi verir, siz o bilgiyi yalanlarsınız yahut onlar size asılsız bir şey söyler, siz de kalkıp onu onaylarsınız.” (İbn Hanbel, el-Müsned, III, 387, 470, 471) ifadelerine yer verilir. Diğer bir rivayette ise, "Ehl-i kitabı ne tasdik ne tekzip edin; Biz, ‘Allah'a ve bize indirilmiş olan vahye iman ettik.' deyin.” (Buhârî, İtisâm, 25; Tevhîd, 42, 51) ifadeleri mevcuttur.

${ }^{71}$ Buhârî, Enbiya, 50.

72 İsrâiloğullarından nakilde bulunmanın keyfiyeti ile ilgili daha geniş bilgi için bkz. Meir Jacob Kister, “İsrâiloğullarından Nakilde Bulunma Meselesi”, trc. Cemal Ağırman, CÜİFD, cilt: 5, sayı: 1 (2001), s.
} 


\section{Klasik Selefî Düşüncede İsrâiliyyât Eleştirisi}

Selefîlik, İbn Teymiyye tarafından sistematik hale getirilmiş bir dinî düşünce ekolüdür. Selefî̀ düşünce geleneğinin Kur'an ve tefsir alanındaki yaklaşımı ilk bakışta tek hat üzerinde irdelenebilir bir izleğe sahip görünse de aslında birbiriyle bağlantılı ve aynı zamanda birbirinden oldukça farklı üç hat üzerinde ele alınması gereken bir konudur. Üç hattan ilki, sistematik Selefîliğe alt yapı oluşturan Ehl-i Hadis ekolüdür. Ashâb-1 Hadîs, Ehl-i Eser, Ehl-i Sünnet-i Hâssa gibi farklı isimlerle de anılan bu ekolün sembol ismi Ahmed b. Hanbel (ö. 241/855)'dir. Hicrî III. asırda İbn Hanbel'in yanı sıra İshâk b. Râheveyh (ö. 238/853), İmam el-Buhârî (ö. 256/870), Ebû Saîd ed-Dârimî (ö. 280/894) gibi âlimlerin katkılarıyla nüfuz ve güç kazanan Ehl-i Hadis ekolü ilerleyen dönemlerde Bağdat merkezli olarak Ebû Bekr el-Hallâl (ö. 311/923), Ebû Muhammed el-Berbehârî (ö. 329/941), İbn Battâ el-Ukberî (ö. 387/997) gibi Hanbelî imamlarınca temsil edilmiştir. ${ }^{73}$

Selefîlik ve tefsir konusunda ikinci hat, hicrî VII. asrın ikinci yarısında yetişen İbn Teymiyye (ö. 728/1328) ile onun İbn Kayyim el-Cevziyye (ö. 751/1350) ve Ebü'l-Fidâ İbn Kesîr (ö. 774/1373) gibi meşhur talebelerince temsil edilen dinî düşünce çizgisidir. Selefîlik özellikle İbn Teymiyye ve İbn Kayyim el-Cevziyye tarafından sistematize edilmiştir. Sistematik Selefîliğin Ahmed b. Hanbel ve Hanbelîlerce temsil edilen Ehl-i Hadis ekolüne dayandığı şüphesizdir. Nitekim İbn Teymiyye, "Akaid konusunda Selef mezhebi/metodu ile müteahhir dönemlerdeki diğer mezhepler hakkındaki görüşünüz nedir? Doğru yoldaki mezhep bunlardan hangisidir? En doğru yol Ehl-i Hadis'in yolu mudur? Fırka-i nâciyeden maksat Ehl-i Hadis midir?” gibi sorulara cevap mahiyetinde şunları söylemiş̧tir: "Ehl-i Hadis akıl yönünden insanların/Müslümanların en olgunu, kıyas yönünden en düzgünü, re’y yönünden en isabetlisi, görüş yönünden en sağlamı, düşünce yönünden en sahihi, istidlal yönünden en sağlıklısı, cedel yönünden en güçlüsü, feraset yönünden en mükemmeli, ilham yönünden en doğrusu, basiret ve mükaşefe yönünden en keskini, dinleme ve konuşma yönünden en isabetlisi, hal (vecd-zevk)

125-153; Veysel Özdemir, "İsrâiliyyât Türü Rivâyetlerin Hükmünü Belirleme Açısından 'Ve Haddisû an Benî İsrâile ve Lâ Harace...” Hadisi Hakkında Bir Değerlendirme”, FÜIFD, sayı: 13/2 (2008), s. 313.

${ }^{73}$ Mustafa Öztürk, "Selefîlik ve Tefsir”, Tarihte ve Günümüzde Selefîlik, İstanbul 2014, s. 191. 
açısından en güzelidir. Hâsılı, diğer din mensuplarına kıyasla Müslümanların konumu neyse sair İslam firkalarına kıyasla Ehl-i Hadis ve Sünnet'in konumu da odur.",74

İbn Teymiyye'nin bu şekilde övdüğü Ehl-i Hadis'in temel referans mercii ise selef-i sâlihîn diye de anılan sahabe, tâbiûn ve tebe-i tâbiîn âlimleridir. Tevbe 9/100, Enfal 8/75 ve Haşr 59/10 gibi ayetler ile "En hayırlı nesil kendilerine peygamber olarak gönderildiğim ilk Müslüman nesildir. İkinci en hayırlı nesil onları takip edenler, daha sonra da onları takip edenlerdir (sahabe, tâbiûn, tebe-i tâbiîn). "75 şeklindeki hadis rivayetinden hareketle selefin peygamberlerden sonra insanların hayırlısı olduğunu söyleyen İbn Teymiyye’ye göre "Selef âlimlerinin ilim ve din hakkındaki görüşlerini ve amellerini bilmek, sonraki nesillerin görüşlerini ve amellerini bilmekten çok daha hayırlı ve faydalıdır. Selef ulemasının tefsir, usûl-i din, furû-ı fikh, zühd, ibadet, ahlak, cihad ve sair alanlardaki görüşlerini ve amellerini bilmek gerekir. Çünkü Kur'an ve Sünnet'in delâlet ettiği üzere selef kendilerinden sonraki tüm nesillerden faziletlidir. Bu sebeple onlara uymak, sonraki nesillere uymaktan, ilim ve din konusunda onların görüş ve tartışmalarını bilmek, sonraki nesillerin görüş ve tartışmalarını bilmekten daha hayırlı ve faydalıdır. Selef ulemasının icmaı masumdur."76

Selefîlik ve tefsir konusunda üçüncü hat, modern dönemdeki 1slah-tecdit söylemiyle ön plana çıkan yeni Selefîliktir. XIX. yüzyılda İslam dünyasının Batı karşısında mağlup duruma düşmesinin sebepleri ve bu kötü durumdan çıkışla ilgili hâl çareleri aranırken birçok Müslüman ilim ve fikir adamı inhitat/inkıraz krizini tarihî tecrübe içerisinde dinin aslî hüviyetini kaybetmesine ve dinî metinlerin (nasslar) yanlış yorumlanıp yanlış uygulanmasına bağlamıştır. Buna göre ilk asırlardan sonra dine çeşitli hurafe ve bidatler sokulmuş, ulema arasında taklit zihniyeti yaygınlaşmış, nassların ve diğer aslî kaynakların yerine fakihler, kelâmcılar ve müfessirlere ait şahsi görüş ve kanaatler önem kazanmış, tasavvuf ve tarikatlar halkı miskinleştirip tembelleştirmiş ve bütün bu sorunlar İslam dünyasının gerilemesi ve Ehl-i küfür karşısında mağlup duruma düşmesi gibi bir sonuca müncer olmuştur. Bu kötü durumu iyiye dönüştürmek ve tarihin akışını yeniden Müslümanların lehine çevirmek için hem

\footnotetext{
${ }^{74}$ Ebü'l-Abbâs Takiyyüddîn İbn Teymiyye, Nakzü'l-Mantık, Kahire 1951, s. 1, 8.

${ }^{75}$ Müslim, "Fezâilü’s-Sahâbe" 210-215; İbn Hanbel, el-Müsned, II, 328; V, 327; VI, 156.

${ }^{76}$ Ebü'l-Abbas Takiyyüddîn İbn Teymiyye, Mecmûu'l-Fetâvâ, Beyrut 2000, XIII, 13-14.
} 
saf İslam'a, yani Kur'an ve Sünnet ile selef-i sâlihînin yoluna dönmek, hem de dinî düşünceyi ıslah etmek kaçınılmazdır. ${ }^{77}$

Selefî̀ düşüncenin tarihsel süreçteki üç farklı evresine ilişkin bu genel bilgilerin ardından belirtmek gerekir ki İsrâiliyyât kelimesinin olumsuz anlamda terimleşmesinde belirleyici rol hiç kuşkusuz İbn Teymiyye (ö. 728/1328) ve talebesi İbn Kesîr'e (ö. 774/1373) aittir. İbn Teymiyye, Kur'an ve sahih hadislere dayalı saf İslam düşüncesinin lehinde ve sağlam bir temele dayanmayan bidatler olarak gördüğü bâtıl inançların aleyhinde konuşurken, kabul etmediği/reddettiği rivayetleri ifade etmek için İsrâiliyyât terimini kullanmıştır. Mesela, Kur'an tefsiri bağlamında bir rivayetle ilgili olarak, "Bu İsrâiliyyât'ta zikredilmiş olup Hz. Peygamber'e ulaşan sahih bir senedi yoktur." demiştir. $^{78}$

İbn Teymiyye Mecmûatü'r-Resâil ve'l-Mesâil adlı eserinde İsrâilî haberlerin sadece merfû mütevâtir nassla sabit olanlarına güvenmenin caiz olduğuna dikkat çekmiş ve bu bağlamda Allah'ın Hz. Âdem'e indirdiği harfler hususunda İbn Kuteybe gibi bazı müelliflerin Allah'ın bu harfleri tek tek ve yazılı olarak indirdiği yönünde rivayetler naklettiklerini belirtmiş ve fakat ardından bu tür rivayetlerin Ka'b el-Ahbâr (ö. 32/652653), Vehb b. Münebbih (ö. 114/732), Mâlik b. Dînar (ö. 131/748), Muhammed b. İshâk (ö. 151/768) gibi Yahudi kaynaklı hikâye ve efsanelerden nakilde bulunan kimselere dayandığını belirtmiştir. İbn Teymiyye'ye göre:

Müslümanlar Vehb b. Münebbih, Ka'b el-Ahbâr gibi isimlerin geçmiş peygamberlerle ilgili olarak naklettikleri İsrâilî hadislerin İslam dininde bir umde kabul edilmesinin caiz olmadığı hususunda hemfikirdir. Bu konuyla ilgili tek cevaz imkânı, söz konusu rivayetlerin mütevatir nakille sübut bulması ya da bizzat Rasûlullah'tan menkul olmasıdır. Âdem'e yazılı bir metin vahyedildiği, (insanlık tarihinde) ilk yazı yazan kişinin İdris (a.s.) olduğu yönündeki rivayetler Kur'an'da ve sahih hadislerde aslı bulunmayan ve kendisine inanılması gerekli olmayan İsrâilî sözler (el-ehâdîsü'lisrâiliyyât) türündendir. Bu rivayetlerin sıhhatini tasdik ancak sağlam bir delille caizdir. Rasûlullah sahih bir hadisinde şöyle buyurmuştur: "Ehl-i kitap size bir şeyler anlattığında ne onları tasdik edin ne de tekzip edin. Zira ihtimal ki onlar size doğru

\footnotetext{
${ }^{77}$ Mustafa Öztürk, Çağdaş İslam Düşüncesi ve Kur'ancılık, Ankara 2013, s. 19.

${ }^{78}$ Tottoli, “İslamî Literatürde İsrâiliyyât Teriminin Kökeni ve Kullanımı”, s. 208.
} 
şeyler anlatır, siz onu yalanlamış olursunuz. Yahut onlar size yalan yanlış şeyler anlatır, siz de onu tasdik etmiş olursunuz.",79

İbn Teymiyye Mukaddimetü't-Tefsîr adlı risalesinde de İsrâiliyyât hakkında önemli şeyler söylemiştir. Bu bağlamda İsmail b. Abdirrahman es-Suddî’nin (ö. 127/744) tefsirindeki rivayetleri genellikle İbn Mesud (ö. 32/652) ve İbn Abbas’tan (ö. 68/687) aktardığını, kimi zaman da bu sahâbîlerden Hz. Peygamber'in Ehl-i kitaptan nakledilmesine izin verdiği türden rivayetler naklettiğini belirtmiş, ayrıca Abdullah b. Amr'ın (ö. 65/684) Yermük Savaşı'nda (15/636) Ehl-i kitaptan iki deve yükü hacminde kaynak elde ettiğine ve bu kaynaklardaki bilgileri nebevi ruhsata dayanarak naklettiğine değinmiştir. $^{80}$

İsrâilî haberlerin itikat alanında değil, ancak iştişhad için kullanılabileceğini söyleyen İbn Teymiyye bu haberlerin genelde üç kısımda değerlendirilebileceği kanaatindedir: (1) Elimizde doğru olduklarına dair İslâmî bilgiler bulunan haberler. Bunlar sahih haberler türündendir. (2) Yalan ve asılsız oldukları elimizdeki delillerle bilinen haberler. (3) Sahih veya asılsız olduğuna dair bilgimiz bulunmayan haberler. Bunlara ne inanırız ne de yalanlarız. Yukarıda geçtiği üzere bunları nakletmek caizdir ve bu tür rivayetlerin çoğu dinî bir meseleyle ilgili faydası olmayan şeylerdir. İsrâilî haberlerde Ehl-i kitap âlimleri de ihtilafa düşmüş ve bu sebeple müfessirler aynı konuda çok farklı rivayetler nakletmişlerdir. Ashab-1 Kehf'in kaç kişi oldukları, isimleri, köpeklerinin rengi, Hz. Musa'nın asasının hangi ağaçtan yapıldığı, Allah'ın Hz. İbrahim için dirilttiği kuşların cinsi, İsrailoğulları içerisinde öldürülen kimseye dirilmesi için sığırın hangi uzvuyla vurulduğu, Allah'ın sesinin Hz. Musa'ya hangi ağaçtan geldiği gibi, Allah'ın Kur'an'ı Kerim'de açıklamayıp kapalı bıraktığı ve açıklanmasında mükellef için dinî veya dünyevî hiçbir fayda bulunmayan hususlar bu kabildendir. ${ }^{81}$

İbn Teymiyye, "[Ey Peygamber!] Şimdi bazıları, "O gençler üç kişiydi, dördüncüleri köpekleriydi."; bazıları, “Aslında onlar beş kişiydi, altıncıları köpekleriydi."; bazıları da "Yok, onlar yedi kişiydi, sekizincileri köpekleriydi." diyerek, bilgi sahibi olmadıkları bir konuda atıp tutacaklar. [Ey Peygamber!] De ki: “Onların kaç

\footnotetext{
${ }^{79}$ Ebü'l-Abbas Takiyyüddîn İbn Teymiyye, Mecmûatü'r-Resâil ve'l-Mesâil, Beyrut 1992, III, 383.

80 İbn Teymiyye, Mecmûu'l-Fetâvâ, XIII, 163.

${ }^{81}$ İbn Teymiyye, Mecmûu'l-Fetâvâ, XIII, 163-164.
} 
kişi olduklarını en iyi rabbim bilir." [Ey Peygamber!] Çok az kimse o gençler hakkında bilgi sahibidir. Şu hâlde, onlar hakkında [sana anlattıklarımız doğrultusunda] kısa ve öz konuşmanın dışında tartışmaya girme. Bu konuda bilir bilmez yere konuşanlardan hiç kimseye de o gençler hakkında soru sorma!" 82 mealindeki ayete atıfta bulunarak İsrâiliyyât konusundaki sağlıklı tutumun nasıl olması gerektiğine de dikkat çekmiştir. Şöyle ki Allah bu ayette Ehl-i kitaptan üç görüş nakletmekte ve bunların ilk ikisini çürütüp üçüncüsü hakkında bir şey söylememektedir. Böylece üçüncü görüşün doğruluğuna delalet etmektedir. Şayet üçüncü görüş de yanlış olsaydı, öncekileri reddettiği gibi bunu da reddederdi. Sonrasında ise Allah, Ashab-1 Kehf’in kaç kişi olduklarını bilmenin herhangi bir yararının olmadığına dikkat çekmiştir. ${ }^{83}$

İbn Teymiyye İktidâu's-Strâti'l-Müstakîm adlı eserinde, Beyt-i Makdis'in faziletlerine dair aktarılan rivayetleri değerlendirirken bu rivayetlerin aslında Ehl-i kitap kaynaklı olduğunu söylemiş ve bu İsrâilî rivayetlerin büyük ölçüde Ka'b el-Ahbâr tarafından nakledildiğine dikkat çekmiştir. Daha sonra Muaviye'nin bir sözüne de atıf yaparak Şam muhitindeki Müslümanların Ka'b el-Ahbâr'dan çok sayıda İsrâiliyyât öğrendiğini belirten İbn Teymiyye İslam ümmetinin tabiûn âlimlerinin rivayetlerini dahi kılı kırk yararak kabul etmelerine karşın Ka'b el-Ahbâr'dan gelen İsrâiliyyât'ı bu denli rahat bir şekilde nakletmelerini hayretle karşıladığından söz etmiştir. Oysaki Ka'b elAhbâr ile kendisinden bilgi aktardığı peygamberler arasında aşağı yukarı bin yılı aşkın bir zaman aralığı vardır. Üstelik bu bilgiler güvenilir raviler ve rivayet zincirleri vasıtasıyla da aktarılmamış, en nihayet eski Yahudi din adamlarına ait metinlerden nakilde bulunulmuştur. Allah Kur'an'da söz konusu din adamlarının tebdil ve tahrif yaptıklarını bildirmiştir. Şu halde bir Müslümanın sırf bu nakillere istinaden herhangi bir İsrâilî haberi doğru kabul etmesi nasıl mümkün olabilir? Bu konuda Müslümanların yapması gereken iş, bu tür haberleri ne peşinen doğru kabul etmek ve ne de -eğer elimizde asılsızlığını gösteren bir delil yoksa- tekzip etmektir. Hz. Peygamber bize böyle davranmamızı emretmiştir. ${ }^{84}$

İbn Teymiyye'nin İsrâiliyyât konusunda menfi tavır takınmasında Ehl-i hadis ve selef çizgisini takip etmesinin yanında yaşadığı döneme damgasını vuran Moğol istilası

\footnotetext{
${ }^{82}$ Kehf $18 / 22$.

${ }^{83}$ İbn Teymiyye, Mecmûu'l-Fetâvâ, XIII, 164.

${ }^{84}$ Ebü'l-Abbas Takiyyüddîn İbn Teymiyye, İktidâü's-Sirâti'l-Müstakîm, Beyrut trs., II, 821-823.
} 
ve Haçlı seferleri gibi büyük hadiseler kuşkusuz etkili olmuştur. İbn Teymiyye'nin bu iki büyük felaketle ilgili kaygıları sadece siyasî değil, aynı zamanda dinî ve ilmî içeriklidir. İbn Teymiyye bir fetvasında Moğol veziri ve tarihçisi Râşidüddîn'in görüşlerine atıfta bulunarak, onların Yahudilik, felsefe ve Râfızilliği mezcederek İslam’1 bozmak istediklerini belirtmiş, ayrıca Cengiz Han yasasına karşı Memlükler’in şeriata sahip çıkmamaları halinde tarihten silineceklerine dikkat çekmiştir. İbn Teymiyye'nin dış saldırılardan Müslümanları koruma çabası kadar dinî kimliğin muhafazasına da önem verdiğini gösteren bir diğer husus, Haçlı seferlerinden sonra Şam diyarında zemin bulan Hıristiyan örf, âdet ve kültürünün Müslümanlar üzerinde az çok tesir bırakması üzerine bu konuda sürekli uyarıda bulunup fetvalar vermiş olmasıdır. ${ }^{85}$

İbn Teymiyye, Haçlı seferlerinin yarattığı veya yaratması muhtemel inanç/fikir krizine ve aynı zamanda Hz. Peygamber'in risaletinin bölgeselliğini iddia eden Hıristiyan söylemine karşı müstakil eserler kaleme almıştır. Mesela, Sayda Piskoposu Pavlus'a nispet edilen bir risaleye reddiye olarak el-Cevâbü's-Sahîh li-men Beddele Dîne'l-Mesîh adlı bir eser yazmıştır. Ayrıca Hz. Peygamber'in şahsiyetini ve dindeki yerini koruyup ona halel getirmemenin bizzat İslam'ın muhafazasıyla eşdeğer bir vazife olduğu bilinciyle Sârimü'l-Meslûl alâ Şâtimi'r-Rasûl adlı bir eser kaleme almıştır. ${ }^{86}$ Ancak kitabın içeriğine bakıldığında İbn Teymiyye, kendi görüşlerini temellendirmek adına Kitab-1 Mukaddes’ten çokça alıntı yapmış ve bunları beşâirü'n-nübüvve bağlamında delil olarak kullanmıştır. ${ }^{87}$

Daha önce değindiğimiz gibi klasik dönemlerde İsrâiliyyât'a çok mesafeli duran âlimlerden biri de İbn Kesîr'dir (ö. 774/1373). Bu konuda hocası İbn Teymiyye'nin çizgisini takip ettiği anlaşılan İbn Kesîr el-Bidâye ve'n-Nihâye adlı eserinin mukaddimesinde İsrâilî haberlerden ancak Allah'ın kitabına ve peygamberin sünnetine ters düşmeyen ve Hz. Peygamber tarafından nakline izin verilen merviyyatın nakledilebileceğini söylemiştir ki bu kapsamdaki İsrâiliyyât ne doğrudan tasdik ne doğrudan tekzip edilebilecek türdendir. İbn Kesîr'e göre nakline izin verilen İsrâiliyyât Kur'an'da kısa ve özlü biçimde anlatılan hususların tafsil edilmesine ya da müphem

\footnotetext{
${ }^{85}$ Ferhat Koca, “İbn Teymiyye, Takıyyüddin”, DİA, İstanbul 1999, XX, 392-393.

${ }^{86}$ M. Sait Özervarlı, İbn Teymiyye'nin Düşünce Metodolojisi, İstanbul 2008, s. 35-38.

${ }^{87}$ Ebü'l-Abbas Takiyyüddîn İbn Teymiyye, el-Cevâbü's-Sahîh li-men Beddele Dîne'l-Mesîh, Riyad 1999, V, 5-318; Koca, “İbn Teymiyye, Takıyyüddin”, DIA, XX, 394-395.
} 
olan birtakım konuların açıklık kazanmasına katkı sağlar. Dahası bu tür İsrâilî rivayetler kendilerine gerçek manada ihtiyaç duyulduğundan veya delil sayıldığından değil, bir tür tezyinat malzemesi gibi kullanılır. Kuşkusuz temel dayanak ve referans Kur'an ve sünnettir. ${ }^{88}$

Buhârî’nin (ö. 256/870) Abdullah b. Amr b. Âs tarikiyle Hz. Peygamber'den naklettiği, "Bir ayet de olsa onu benden nakledin. İsrailoğullarından da haberler nakledin. Bunda bir sakınca yoktur. Benden hadis nakledin; ancak bana yalan isnad etmeyin. Her kim kasıtlı olarak bana yalan isnad ederse, ateşteki yerini hazırlasın." hadisi $^{89}$ İbn Kesîr'e göre naklinde sakınca olmayan, aynı zamanda tasdik ve tekzip edilmesine ilişkin bir delil bulunmayan İsrâilî haberlerle ilgilidir. İslam dinindeki deliller İsrâiliyyat'ın bir kısmının doğru olduklarına şahitlik eder; fakat İslam'daki deliller ve haberler bu rivayetlerin kullanımına ihtiyaç hissettirmez. İslam dini açısından bâtıl hükmünde olan İsrâilî haberler ise en başından merdut olup nakli caiz değildir. Bu tarz rivayetler/haberler ancak inkar ve iptal maksadıyla nakledilebilir. İbn Kesîr'in ifadesiyle, "Her tür övgüye layık, noksanlıklardan münezzeh yüce Allah bizi Hz. Muhammed sayesinde diğer şeriatlara ve Kur'an'1 Kerim ile de diğer kitaplara muhtaç olmaktan/kalmaktan kurtardığına göre İsrailoğulları'nın yalan, yanlış, uyduruk, muharref haberlerine göz atacak ve bunları kullanacak değiliz."90

İbn Kesîr, “Hani meleklere ‘Âdem'e secde edin', demiştik de İblis’ten başka hepsi secde etti." mealindeki Kehf 18/50. ayetin tefsirinde, İblis'in mahiyetinin, cinlerden mi yoksa melek taifesinden mi oluşuna ve Âdem'e secde etmemesine dair çeşitli rivayetleri naklettikten sonra, bu konuda seleften pek çok haber rivayet edildiğini, çoğunluğunu İsrâiliyyât'ın oluşturduğu bu tarz haberlerden bir kısmının sadece haberdar olunmak için aktarılabileceğini söylemiştir. Çünkü bu haberlerin en doğrusunu sadece Allah bilir. İsrâilî haberlerin bir kısmının, elimizde bulunan gerçeğe ters düşmesi nedeniyle kesin olarak yalanlanması gerekliliğini vurgulayan İbn Kesîr bu bağlamda da “Kur’an, geçmiş

\footnotetext{
${ }^{88}$ Ebu'l-Fidâ İmâdüddîn İsmâil b. Ömer İbn Kesîr, el-Bidâye ve'n-Nihâye, thk. Abdullah b. Abdülmuhsin et-Türkî, Cize 1998, I, 7.

${ }^{89}$ Buhârî, Enbiya, 50.

90 İbn Kesîr, el-Bidâye ve'n-Nihâye, I, 7-8.
} 
haberler için başka bir kaynağa ihtiyaç bırakmaz. Çünkü o her tür tebdil ve tahriften, ziyadelik ve noksanlıktan korunmuş yegâne kitaptır." demiştir. ${ }^{91}$

İbn Kesîr, İsrâilî haberlerin nakledilmesi ve İslâmî kaynaklara girmesi konusunda öncü rolüne sahip olan Ka'b el-Ahbâr, Vehb b. Münebbih gibi isimlerle ilgili dikkat çekici değerlendirmelerde de bulunmuştur. Bu bağlamda Ka'b el-Ahbâr'ın, Hz. Ömer (ö. 24/644) zamanında Müslüman olduğundan ve Hz. Ömer'in huzurunda Ehl-i kitap kaynaklı bilgiler aktardığından söz eden İbn Kesîr Hz. Ömer'in, Ka'b'ın gönlünü İslam'a ısındırmak amacı ile onun anlattıklarına kulak verdiğine dikkat çekmiş, bu arada Ka'b el-Ahbâr'ın rivayetlerinde birçok yanlış bilginin bulunduğunu da belirtmiştir. ${ }^{92}$ Nitekim Bakara 2/102. ayetin tefsirinde Ka'b el-Ahbâr'dan rivayetle, melekler Âdemoğulları'nın işledikleri suçları teker teker saydıklarında, kendilerine “Aranızdan iki kişiyi seçin.” diye buyrulduğunu ve onların da Hârût ve Mârût adlı iki meleği seçtiklerine dair haberleri nakletmiş, ardından da bu haberlerin İsrailoğullarına ait bir uydurma olduğunu söylemiştir. ${ }^{93}$

İbn Kesîr, Bakara 2/36. ayetin tefsirinde ise Vehb b. Münebbih'in yılan hikâyesi, şeytan kıssası, İblis'in cennete nasıl girdiği, şeytanın Hz. Âdem'i nasıl aldattığı gibi birçok haber rivayet ettiğini ve bütün bu rivayetlerin İsrâiliyyât hurafeleri olduğunu söylemiştir. ${ }^{94}$ Yine İbn Kesîr, Şuarâ 26/140. ayet münasebetiyle, Hz. Hud ve onun kavmi hakkındaki birtakım nakillere yer verdikten sonra ayette geçen Irem kelimesinin şehir olduğunu sananların Ka'b ve Vehb'in İsrâiliyyât'a dayalı nakillerinden hareketle bu kanaate vardıklarını ve fakat söz konusu nakillerin aslının bulunmadığını belirtmiştir. ${ }^{95}$

İbn Kesîr Kâf suresinin başındaki kâf harfinin yeryüzünü çepeçevre kuşatan ve "Kaf Dağı”" diye adlandırılan bir dağ olduğu yolundaki selef rivayetlerine dair değerlendirmesinde de İsrâiliyyât'a dair şunları söylemiştir:

\footnotetext{
${ }^{91}$ İbn Kesîr, Tefsîru'l-Kur'âni'l-Azîm, IX, 155.

92 İbn Kesîr, el-Bidâye ve'n-Nihâye, I, 34-35.

${ }^{93}$ İbn Kesîr, Tefsîru'l-Kur'âni'l-Azîm, I, 524-525.

94 İbn Kesîr, Tefsîru'l-Kur'âni'l-Azîm, I, 366.

95 İbn Kesîr, Tefsîru'l-Kur'âni'l-Azîm, X, 361.
} 
Rivayete göre bazı selef âlimleri kâf harfinin bütün dünyayı kuşatan ve Kâf Dağ1 diye adlandırılan bir dağa işaret ettiğini söylemişlerdir. Öyle görünüyor ki -en doğrusunu Allah bilir- bu görüş İsrailoğulları'ndan alınmış bir hurafedir. Belli ki bu hurafeyi nakleden kimseler, tasdik ve tekzip edil(e)meyen türden İsrâilî haberlerin Ehl-i kitaptan nakledilmesinin caiz olduğu kanaatine sahiptir. Bana göre bu ve benzeri haberler İsrailoğulları içindeki bazı zındıkların uydurmalarıdır. Onlar bu tür haberlerle insanların dinî inançlarını ifsat etmektedirler. Rasûlullah [daha dün denebilecek kadar yakın bir geçmişte ahirete intikal etmesine], üstelik onca büyük âlim, hadis hafızı ve ilim önderinin mevcudiyetine rağmen İslam ümmeti bünyesinde onun adına birtakım hadisler uydurulduğu gerçeği dikkate alındığında, İsrailoğullarına mensup o zındıkların çok uzun bir zaman dilimi içerisinde kendi ümmetlerinin başına ne çoraplar ördüklerini varın siz düşünün. Kaldı ki İsrailoğulları ümmetinde münekkit hadis hafızları yok denecek kadar azdır. İsrailoğulları içki içer, içlerindeki âlimler [kutsal metinlerdeki] ifadeleri asıl anlamlarından çarpıtarak yorumlar (tahrif), Allah'ın kitaplarını, ayetlerini değiştirirlerdi (tebdil). Evet, Şârî [Rasûlullah], “İsrailoğullarından rivayette bulunabilirsiniz; bunda beis yok." demiş; fakat bu konudaki cevazı aklın kabul edilebilirliğine hükmettiği şeylere mahsus kılmıştır. Aklen muhal görülüp bâtıl olduğuna hükmedilen, zann-1 galiple de yalan olduğu bilinen hususlara gelince, cevaz hükmü bu hususlarda geçerli değildir. Hâl böyleyken, ilk dönemlerdeki pek çok müfessir ile sonraki kuşaklardan bir grup âlim yüce Kur'an'ın tefsirinde Ehl-i kitaba ait metinlerden birtakım hikâyeler nakletmiştir. Hâlbuki bu müfessirler Kur'an tefsirinde Ehl-i kitap haberlerine/rivayetlerine muhtaç değildir. ${ }^{96}$

Ehl-i hadis ve Selefî̀ düşünce geleneğinde İsrâiliyyât rivayetlerini değerlendirme ölçütlerine gelince, bu konuyla ilgili temel ölçütlerden biri, hatta birincisi rivayette sübutla ilgilidir. Nitekim genelde tefsir, özelde İsrâiliyyât türü rivayetler daha ziyade sübut açısından problemli kabul edilir. İbn Abbas'a nispet edilen tefsir rivayetleri bu alandaki problemin ciddiyetini göstermeye kâfidir. İbn Abbas'tan gelen sayısız tefsir rivayetindeki çelişkiler sebebiyle ilgili rivayetlerin tarikleri tek tek belirlenmiş, meşhur tarikler içinde Muaviye b. Salih-Ali b. Ebî Talha tarikinin en sağlam tarik olduğu tespit edilmiş, Muhammed b. Sâib el-Kelbî tariki ise en zayıf ve problemli tarik olarak

\footnotetext{
${ }^{96}$ İbn Kesîr, Tefsîru'l-Kur'âni'l-Azîm, IV, 221.
} 
değerlendirilmiştir. ${ }^{97}$ Buna rağmen Ehl-i hadis ve selef düşüncesinin öncü ismi Ahmed b. Hanbel, "Üç şeyin aslı yoktur. Bunlar tefsir, melâhim ve meğazidir." demiştir. Bazı kaynaklarda bu sözün Ehl-i kitaptan nakilde bulunmanın caiz olup olmadığı ve erken dönemlerde Ehl-i kitaptan nakledilen rivayetlerin nasıl ele alınması gerektiği meselesi bağlamında zikredilmiş olmas ${ }^{98}$ klasik dönemlerdeki İsrâiliyyât değerlendirmesinde Ehl-i hadise mahsus ilim ve ilimde sübut/sıhhat anlayışının belirleyici rol oynadığını gösterir.

Diğer taraftan İbn Teymiyye ve İbn Kesîr gibi selefî âlimlerin İsrâiliyyât konusundaki menfi tutumlarını gerekçelendirme tarzı da Ehl-i hadis ekolünün ilim anlayışıyla örtüşür. Ehl-i hadise göre ilim aslında nakil (rivayet) veya daha spesifik olarak merfu, mevkuf, maktu gibi türleriyle hadis demektir. Bu anlamda ilmin sihhati, muhtevadan ziyade nakil zincirinin sağlamlığına bağlıdır. Kur'an tefsirine dair bir naklin/rivayetin sahih ve sağlam kabul edilmesi, öncelikle ve özellikle senedin herhangi bir illetle malul olmaması ve o senette yer alan ravilerin sika/güvenirlik onayı almasına bağlıdır. Bu açıdan bakıldığında, tefsir kitaplarındaki rivayetlerin pek çoğunun senet ve ravi açısından onaylanması zordur. Ahmed b. Hanbel'in "Üç şeyin aslı yoktur." sözündeki üç şeyden birinin tefsir olması da buna atıfta bulunur. Daha açıkçası, İbn Hanbel, "Tefsirin aslı yoktur." derken, tefsir rivayetlerinin sağlam isnat zincirinden yoksun olduğunu kastetmiştir. İbn Teymiyye bu konuya dair şöyle demiştir:

Bilindiği gibi tefsire dair nakillerin çoğu, melâhim ve meğazi ile ilgili nakiller gibidir. Bu yüzden İmam Ahmed b. Hanbel "Tefsir, melâhim ve meğaziye dair rivayetlerin isnadı yoktur" demiştir. Bu üç alanla ilgili rivayetler asılsız, yani isnatsız rivayet edilir. Dahası, bunlar çoğunlukla mürsel rivayetlerdir. Tıpkı Urve b. Zübeyr, Şa’bî, Zührî, Musa b. Ukbe, İbn İshâk ile bunları takip eden Yahya b. Saîd el-Emevî, Velîd b. Müslim, Vâkıdî gibi meğazi müelliflerinin naklettikleri rivayetlerde olduğu gibi. $^{99}$

\footnotetext{
${ }^{97}$ Muhammed Hüseyin ez-Zehebî, et-Tefsîr ve'l-Müfessirûn, Beyrut trs., I, 53-55.

${ }^{98}$ İbn Teymiyye, Mecmûu'l-Fetâvâ, XIII, 154; Ebü'l-Fazl Celâlüddîn Abdurrahmân es-Suyûtî, el-Ittkân fi Ulûmi'l-Kur'ân, Beyrut 2002, II, 1202.

${ }^{99}$ İbn Teymiyye, Mecmûu'l-Fetâvâ, XIII, 154-155.
} 
Bu noktada İbn Teymiyye ile talebesi İbn Kesîr'in İsrâiliyyât konusundaki menfi tutumlarında Müslümanlar ile Yahudiler ve Hıristiyanlar arasında yaşanan tartışma, zıtlaşma ve çatışmaların hatırı sayılır ölçüde rol oynadığı tespitinde bulunulabilir ve bu tespit İbn Kesîr'in “Zebîh İshak mı yoksa İsmail mi?” sorusuna cevap teşkil eden şu ifadeleriyle teyit olunabilir: "İlim ehlinden bazı kimseler zebîhin İshak olduğu görüşünü benimsemiştir. $\mathrm{Bu}$ görüş bir grup selef âliminden, hatta bazı sahâbîlerden de nakledilmiştir. Oysa Kur'an ve Sünnet'te ifade edilen husus bu minvalde değildir. Kanımca söz konusu görüş Kitâbî (Yahudi) din adamlarından alınmış ve sağlam bir delilden yoksun olmasına rağmen kesin doğru [gibi] kabul edilmiştir."100

Görüldüğü gibi İbn Kesîr, Hz. İbrahim'in kurban edilecek evladının İshak olduğuna ilişkin görüşün Ehl-i kitap menşe'li ve aynı zamanda delilsiz olduğunu ileri sürmüştür. Hâlbuki bu görüş erken dönemlerde çoğunluk ulemanın görüşü olarak nakledilmiştir. Mesela, Nehhâs (ö. 338/950) çoğunluk âlimlerin "İshak” görüşünü benimsediğini söylemiş ve sahabeden Abbas b. Abdilmuttalib, Abdullah b. Abbas, Abdullah b. Mes'ûd, Câbir b. Abdillah, Hz. Ali, Hz. Ömer, Abdullah b. Ömer'i, tâbiûn ve tebe-i tâbiînden Saîd b. Cübeyr, Mücâhid, İkrime, Katâde, Atâ, Zührî, Süddî, Alkame, Şa'bî, Mesrûk, Mâlik b. Enes, Ka'b el-Ahbâr, Kâsım b. Ebî Bezze, Abdullah b. Ebî Hüzeyl, Mukâtil gibi âlimleri de bu görüşü benimseyenler arasında zikretmiş,; ${ }^{101}$ ayrıca Taberî (ö. 310/923) zebîhin İshak olduğu görüşünde 1srar etmiştir. ${ }^{102}$

Zebîh meselesindeki tercihinden de anlaşılmış olacağı üzere İbn Kesîr İsrâiliyyât'1 kabul ve ret hususunda naklî bilginin Yahudi din adamlarından gelmesini ve dolayısıyla sağlam bir delile dayanmamasını belirleyici ölçüt kılmış, buna mukabil kimi zaman da Fahreddîn er-Râzî gibi Sünnî müfessirlerin ismet-i enbiya fikriyle bağdaşmaz olarak görüp kesinkes reddettiği izahlara paralel görüş beyan etmekte sakınca görmemiştir. Bununla ilgili bir örnek vermek gerekirse, Sâd 38/33-34. ayetlerin erken dönem tefsir kaynaklarındaki izahına göre Hz. Süleyman soylu atları temaşa ederken namazı unutmuş ve bu durumu, "Atları sevmekle meşguliyetim rabbimi anmaktan beni alıkoydu." (innî ahbebtü hubbe'l-hayri an zikri rabbî) diye ifade etmiş, ardından da

\footnotetext{
${ }^{100}$ İbn Kesîr, Tefsîru'l-Kur'âni'l-Azîm, IV, 14.

${ }^{101}$ Ebû Cafer Ahmed b. Muhammed en-Nehhâs, I'râbü'l-Kur'ân, thk. Züheyr Ğâzî Zâhid, Beyrut 1988, III, 431-432.

${ }^{102}$ Taberî, Câmiü'l-Beyân fì Tefsîri'l-Kur'ân, X, 514-515.
} 
atların boyunlarını vurup bacaklarını kesmiştir (fe-tafika meshan bi's-sûki ve'l-a'nâk). $\mathrm{Bu}$ izah, "Bir Peygamber hayvanlara eziyet etmez, yok yere kendi malını da telef etmez..." gerekçesiyle Taberî tarafından pek isabetli görülmemiş, ${ }^{103}$ Fahreddîn er-Râzî tarafından da kesin bir dille reddedilmiştir. Buna mukabil İbn Kesîr birçok selef âlimince de tercih edilen mezkûr izahı isabetli bulmuş ve bu konuda Hz. Peygamber'in Hendek savaşı sırasında ikindi namazını kaçırmasına atıfta bulunmuştur. ${ }^{104}$

$\mathrm{Bu}$ örnekten anlaşılacağı gibi İbn Kesîr nazarında İsrâiliyyât türü bir rivayetin kabulü hususunda temel ölçüt, ilgili rivayetteki muhtevanın İslam şeriatında müspet bir karşılığının bulunması ve bunun Hz. Peygamber'e aidiyeti sübut bulmuş bir nakille teyit olunmasıdır. Şayet böyle bir nakil mevcutsa, bu nakil İsrâilî rivayetin kabulü veya en azından reddedilmemesi hususunda hüccettir. Aksi halde söz konusu rivayet reddedilebilir. Örnek vermek gerekirse, Hz. Dâvûd, iki hasım ve doksandokuz koyun/kadın kıssasıyla ilgili olarak müfessirlerin İsrâiliyyât kaynaklı birçok rivayet naklettiğini belirten İbn Kesîr bu konuda Rasûlullah'a aidiyeti sabit bir haber bulunmadığından söz etmiş, ardından “Gerçi İbn Ebî Hâtim bir hadis nakletmiştir; ama bu hadisin senedi problemlidir." demiş ve sonunda şunu söylemiştir: "Senedi sağlam bir hadis bulunmadığına göre bu konuda yapılacak en doğru iş, Kur'an'ın zikrettiklerini okumakla yetinip, ilgili ayetlerde ne kastedildiğini Allah'a havale etmektir.",105

\footnotetext{
${ }^{103}$ Taberî, Câmiü'l-Beyân fî̀ Tefsîri'l-Kur'ân, X, 579.

104 İbn Kesîr, Tefsîru'l-Kur'âni'l-Azîm, IV, 33-34.

105 İbn Kesîr, Tefsîru'l-Kur'âni'l-Azîm, IV, 31.
} 


\section{Sonuç}

İslam ilim ve kültür geleneğinde, daha ziyade tefsir ve hadis literatüründe yer alan İsrâiliyyât kelimesinin nasıl ve ne zaman ortaya çıktığı, terim ve kavram olarak ilk ne zaman kullanılmaya başlandığı konusu özellikle modern dönemde birçok Müslüman ve Oryantalist araştırmacıyı meşgul etmiştir. Sözlük anlamları üzerinde ciddi ihtilaf bulunmamakla birlikte İsrâiliyyât teriminin nasıl anlaşılması gerektiği hususunda herkesin tam manasıyla üzerinde ittifak ettiği bir tanım geliştirilememiştir.

İsrâiliyyât her ne kadar ağırlıklı olarak Yahudi kültüründen İslam kaynaklarına girmiş rivayetler ve daha ziyade Kur'an kıssalarıyla ilgili haberleri ifade eden bir anlam ve kullanıma sahip bir terim olarak algılansa da, bu terimin anlam alanına Hiristiyanlık ve diğer din ve kültürlere ait bilgi ve haber malzemesi de kuşkusuz dahildir.

İsrâiliyyât erken dönemlerde Mes'ûdî gibi bazı kültür tarihçileri tarafindan Yahudilik ve Hıristiyanlık gibi farklı kültür ve medeniyetlere ait bilgilerin kaynağını ifade maksadıyla kullanılırken, özellikle İbn Teymiyye ve İbn Kesîr gibi âlimlerin bakış açısı ve tanımlamasıyla olumsuz bir içerik kazanmış bir terimdir. Bu bağlamda İslam geleneğindeki inanç ve ahlak prensipleriyle bağdaşmaz nitelikteki haber ve bilgilerin genel olarak İsrâiliyyât diye kategorize edilmesi İbn Teymiyye ve İbn Kesîr'in eserlerinde sistematik bir şekilde yer bulmuştur. Bu âlimler Kur'an ve sahih hadislere dayalı saf İslam düşüncesinin lehinde veya sağlam bir temele dayanmayan bidatler olarak gördükleri bâtıl inançların aleyhindeki fikirleri beyan ederken, reddettikleri bilgi kaynaklarını ifade maksadıyla İsrâiliyyât terimini kullanmışlardır. İbn Teymiyye'nin İsrâiliyyât konusunda menfi tavır takınmasında Ehl-i hadis ve selef çizgisini takip etmesinin yanında yaşadığı dönemin İslam dünyasında derin yaralar açan Moğol istilası ve Haçlı seferleri gibi büyük hadiseler etkili olmuştur.

Klasik İbn Teymiyye selefîliğinde İsrâiliyyât karşıtlığı önemli ölçüde rivayet ve sübut problemiyle ilgilidir. Bunun yanında İslam şeriatına ve akla aykırılık gibi itiraz gerekçelerinden de söz edilebilir. Ancak sübut problemi bu gerekçelerden daha önemli ve önceliklidir. Burada İsrâiliyyât karşıtlığg daha ziyade Ehl-i hadisin rivayette sahihlik ölçütlerine göre gerekçelendirilirken, Fahreddîn er-Râzî bunu kelâmî-itikâdî bir zemine taşımış, Sünnî-Eş’arî kelam sistemindeki Allah tasavvuru ile ismet-i enbiyâ fikrine 
aykırı muhtevaya sahip bir bilgi-haber olduğu takdirde reddedilmesi gereken bir rivayet malzemesi olarak değerlendirmiştir.

Kaynaklarda vürut sebebi ve zamanı hakkında yeterli bilgi bulunmamakla birlikte Hz. Peygamber'in, "Ehl-i kitaptan nakilde bulunun; bunda beis yoktur" (Buhârî, "Enbiya" 50) hadisinin özgüveni yansıtır nitelikte olduğundan söz edilebilir. Buna mukabil "Ehl-i kitabı ne tasdik, ne tekzip edin" (Buhârî, "İ'tisâm” 25) anlamındaki hadisin Yahudi ve Hıristiyan kültüründen istifade imkânını nefyetmekten ziyade, Yahudilerle bir arada yaşama tecrübesine sahne olan Medine muhitinde Müslüman kimliği inşa sürecinde melezleşme riskini dikkate almayı, dolayısıyla ihtiyatlı davranmayı salık verir mahiyettte olduğu tespitinde bulunulabilir.

Kald1 ki Kur'an'ın muhtelif ayetlerinde Ehl-i kitabın Tevrat ve İncil diye adlandırılan kutsal metinlerine atıfla kendisinin "musaddık" olduğu belirtilmişs (Mâide 5/48), yine bazı ayetlerde "Zikir ehline sorun" (Yûnus 10/94; Enbiyâ 21/7) gibi ifadelerle genelde Ehl-i kitap, özelde Yahudiler referans gösterilmiştir. Ancak Medine döneminde Yahudilerle Müslümanlar arasındaki ilişkilerin gerginleşmesine bağlı olarak, Ehl-i kitap hakkındaki değerlendirmeler ciddi biçimde menfileşmiştir. Nüzul ortamındaki tarihî bağlam ışığında, Kur'an'ın Ehl-i kitaba yönelik dil ve üslubundaki değişikliğin teolojik olmaktan ziyade, siyasi ve stratejik süreçle ilgili olduğu söylenebilir.

İsrâiliyyât'ın kaynak ve bilgi değeri meselesine gelince, genel olarak İslam dünyasında bu konuyla ilgili olarak İbn Haldûn’un, “Araplar ilâhî kitap/vahiy kültürüne ve bilgisine sahip olmayan bir toplumdur. Bu toplumun baskın karakteri göçebelik ve ümmîliktir. Onlar beşerî merakı celbeden mükevvenatın varoluş sebepleri, yaratılışın başlangıcı ve varlık âleminin sırları gibi konularda bilgi sahibi olmak istediklerinde, kendilerinden önce vahiy kültürüne sahip olan Yahudiler ve Hıristiyanlara başvurup onların bilgilerinden istifade ediyorlardı. Ne var ki o dönemde Araplarla aynı muhiti paylaşan Tevrat ehli de göçebe olarak yaşıyor, dolayısıyla Ehl-i kitabın avam zümresi ne biliyorsa onlar da o kadar şey biliyordu." şeklindeki ifadeleri esas alınmakta ve bu bağlamda İsrâiliyyât'ın sağlam bilgi kaynaklarına dayanmadığı vurgulanmaktadır. Ancak bize göre İbn Haldûn'un söz konusu ifadeleri genellemeci bir anlayışı yansitmaktadir. 
Hz. Peygamber döneminde Abdullah b. Amr, Ebü'l-Celd el-Cevnî gibi bazı sahâbîlerin kadim din ve kültürlere ait metinleri okudukları veya en azından bu kültürlere aşina oldukları bilinmektedir. Ayrıca sahabeden Abdullah b. Selam, Selmân-1 Fârisî, Temîm ed-Dârî gibi isimler ile tâbiûn neslinden Ka’b el-Ahbâr ve Vehb b. Münebbih gibi isimlerin de eski kültürlere ait yazılı kaynaklara az çok vukuf sahibi oldukları şüphesizdir. Diğer taraftan Medine'deki Yahudilerin “Beytü'l-Midraş (Midrâs)" diye adlandırılan ve dinî ritüelleri icra, kutsal metinleri müzakere gibi muhtelif amaçlar için kullanılan bir müesseseye sahip oldukları, Hz. Ömer gibi bazı sahâbîlerin bu müesseseyi ziyaret edip tartışmaya katıldıkları birçok tarihî bilgiyle sabittir. Bütün bu bilgiler ve veriler göz önüne alındığında, gerek sahabe ve tâbiûn neslinin, gerek nüzul dönemindeki Yahudi cemaatinin avam düzeyinde bilgi ve donanım sahibi olduğunu söylemek pek isabetli olmasa gerektir.

Bütün bunlara binaen denebilir ki İsrâiliyyât, İslam'ın erken dönemlerinde Müslümanın dünya görüşünü şekillendiren ve aynı zamanda hayat tecrübesine yön veren, dolayısıyla suje ile obje arasındaki ilişkinin bir ürünü olmanın çok ötesinde pratik hayata akseden bir kavramsal içeriğe sahiptir. 


\section{Kaynakça}

Aclûnî, İsmail b. Muhammed, Keşfü'l-Hafâ ve Müzîlü'l-İlbâs, Dımeşk 2001.

Albayrak, İsmail, Qur'anic Narrative and Isra 'iliyyat in Western Scholarship and in Classical Exegesis, The University of Leeds Deparment of Theology and Religious Studies, 2000.

Aydemir, Abdullah, Tefsirde İsrâiliyyat, Beyan Yayınları, İstanbul 2000.

Besalel, Yusuf, "Yaakov (Avinu)", Yahudilik Ansiklopedisi, Gözlem Gazetecilik Basın ve Yayın A.Ş., İstanbul 2002. , "Yisrael”, Yahudilik Ansiklopedisi, Gözlem Gazetecilik Basın ve Yayın A.Ş., İstanbul 2002.

Buhârî, Ebû Abdillâh Muhammed b. İsmail, el-Câmiü's-Sahîh, İstanbul 1981.

Cevâlikî, Ebû Mansûr Mevhûb b. Ahmed b. Muhammed, el-Muarreb mine'lKelâmi'l-A'cemi alâ Hurûfi'l-Mu'cem, thk. F. Abdürrahim, Dımeşk 1990.

Ebû Şehbe, Muhammed, el-İsrâiliyyât ve'l-Mevzuât fî Kütübi't-Tefsîr, Kahire 1987.

Emîn, Ahmed, Fecrü'l-İslâm, Kahire trs.

Fahreddîn er-Râzî, Ebû Abdillah Muhammed b. Ömer, et-Tefsîru'l-Kebîr (Mefâtihu'l-ĞGyb), Beyrut 2004.

Furat, Ahmet Suphi, "Ya'küb”, $\dot{I} A$, İstanbul 1993.

Gazâlî, Ebû Hamid Muhammed b. Muhammed, İhyâu Ulûmi'd-Dîn, Endenozya trs.

Gökkır, Necmettin, “Kur'an Dilinde Ehl-i Kitap Kültürünün İzleri: SosyoLinguistik Bir Yaklaşım”, Tarihten Günümüze Kur'an'a Yaklaşımlar, 2010.

Harman, Ömer Faruk, “İsrail (Benî İsrail)”, DİA, İstanbul 2001.

Hatiboğlu, İbrahim, "İsrâiliyat”, DİA, İstanbul 2001.

Hıdır, Özcan, Yahudi Kültürü ve Hadisler, İnsan Yayınları, İstanbul 2006.

İbn Âşûr, Muhammed Tâhir, et-Tahrîr ve't-Tenvîr, Tunus 1997.

İbn Atıyye, Ebû Muhammed Abdülhak b. Galib, el-Muharrerü'l-Vecîz fî Tefsîri Kitâballâhi'l-Azîz, Beyrut 1422.

İbn Hanbel, Ebû Abdillah Ahmed, el-Müsned, Beyrut trs. 
İbn Kesîr, Ebu'l-Fidâ İmâdüddîn İsmâil b. Ömer, el-Bidâye ve'n-Nihâye, thk. Abdullah b. Abdülmuhsin et-Türkî, Cize 1998. Tefsîru'l-Kur'âni'l-Azîm, thk. Mustafa es-Seyyid Muhammed vd., Kahire 2000.

İbn Manzûr, Ebü'l-Fazl Muhammed b. Mükerrem b. Ali el-Ensârî, Lisânü'l-Arab, Beyrut 1994.

İbn Teymiyye, Ebü'l-Abbas Takiyyüddîn, el-Cevâbü's-Sahîh li-men Beddele Dîne'l-Mesîh, Riyad 1999.

__ İktidâü's-Sirâti'l-Müstakîm, Beyrut trs.

__., Mecmûatü'r-Resâil ve'l-Mesâil, Beyrut 1992.

_. Mecmûu'l-Fetâvâ, Beyrut 2000.

_. Nakzü'l-Mantık, Kahire 1951.

İbnü'l-Arabî, Ebû Bekr Muhammed, Ahkâmu'l-Kur'ân, Beyrut 2003.

Jeffery, Arthur, The Foreign Vocabulary of The Qur'ân, Leiden, Boston 2007.

Kâtip Çelebi, Hacı Halife Mustafa b. Abdillah, Keşfü'z-Zünûn 'an Esâmi'l-Kütüb ve'l-Fünûn, nşr. Muallim Rifat-Şerafeddin Yaltkaya, İstanbul 1941.

Kaya, Mesut, Çă̆daş Tefsirlerde İsrâiliyata Yaklaşım ve Kitab-ı Mukaddes Bilgilerinin Kullanımı, (Yayımlanmamış Doktora Tezi), NEÜSBE, Konya 2013.

Khoury, Raif Georges, Wahb b. Munabbih der Heidelberger Papyrus PSR heid Arab 23: leben und werk des dichters, Otto Harrassowitz, Wiesbaden 1972.

Kister, Meir Jacob, "İsrâiloğullarından Nakilde Bulunma Meselesi", trc. Cemal Ağırman, CÜIFD, cilt: 5, sayı: 1 (2001). , "The Sirah Literature", Arabic Literature to the End of The Umayyad Period, Cambridge University, Cambridge 1983.

Koca, Ferhat, “İbn Teymiyye, Takıyyüddin”, DİA, İstanbul 1999.

Kurtubî, Ebû Abdillah Muhammed, el-Câmi' li Ahkâmi’l-Kur'ân, Beyrut 1988.

Makdisî, Ebû Nasr Mutahhar b. Tâhir, el-Bed' ve 't-Târîh, Bağdat trs.

Mes'ûdî, Ebü'l-Hasan Ali b. Hüseyin b. Ali, Murûcu'z-Zeheb ve Meâdinü'lCevher, ed. Charles Pellat, Beyrut 1970-1979.

Muhibbî, Muhammed Emin b. Fazlullah b. Muhibbillah ed-Dimeşkî, Kasdü'sSebîl fi'l-Lugati'l-Arabiyye mine'd-Dahîl, thk. Osman Mahmûd Sinnî, Riyad 1994.

Mustafavî, Allâme, et-Tahkîk fî Kelimâti'l-Kur'ân, Kahire-Beyrut 2009. 
Müslim, Ebu'l-Hüseyn Müslim b. Haccâc, el-Câmiu's-Sahîh, İstanbul 1981.

Na'nâa, Remzi, el-İsrâiliyyât ve Eseruhâ fî Kütübi 't-Tefsîr, Dımeşk-Beyrut 1970.

Nehhâs, Ebû Cafer Ahmed b. Muhammed, I'râbü'l-Kur'ân, thk. Züheyr Ğâzî Zâhid, Beyrut 1988.

Özdemir, Veysel, “İsrâiliyyât Türü Rivâyetlerin Hükmünü Belirleme Açısından 'Ve Haddisû an Benî İsrâile ve Lâ Harace..." Hadisi Hakkında Bir Değerlendirme”, FÜIFD, say1: 13/2 (2008).

Özervarl1, M. Sait, İbn Teymiyye’nin Düşünce Metodolojisi, İstanbul 2008.

Öztürk, Mustafa, Çăgdaş İslam Düşüncesi ve Kur'ancılık, Ankara 2013. , "İslam Tefsir Geleneğinde Ehl-i Kitapla İlgili Bazı Telakkilerin Epistemik Değeri”, Kur'an ’ın Farklı İnanç Mensuplarına Yaklaşımı, Sempozyum, Mayıs 2007. , “Selefîlik ve Tefsir”, Tarihte ve Günümüzde Selefilik, İstanbul 2014. , Tefsirin Halleri, Ankara Okulu Yayınları, Ankara 2013.

Sa'lebî, Ebû İshâk Ahmed, el-Keşf ve'l-Beyân, Beyrut 2004.

Suyûtî, Ebü'l-Fazl Celâlüddîn Abdurrahmân, el-İtkân fì Ulûmi'l-Kur'ân, Beyrut 2002.

Taberî, Ebû Câ'fer Muhammed b. Cerîr, Câmiü'l-Beyân fî Tefsîri'l-Kur'ân, Beyrut 1995.

Tirmizî, Ebû İsa Muhammed b. İsa, el-Câmiu's-Sahîh, İstanbul 1981.

Tottoli, Roberto, “İslamî Literatürde İsrâiliyyât Teriminin Kökeni ve Kullanımı”, trc. Mesut Kaya, Marife, yıl: 10; sayı: 2 (2010).

Tûfî, Ebü'r-Rebî' Necmüddîn Süleymân, el-íksîr fì Ilmi’t-Tefsîr, nşr. thk. Abdulkâdir Hüseyn, Kahire trs.

Turtuşî, Ebû Bekr Muhammed, Sirâcü'l-Mülûk, Kahire 1994.

Ünver, Mustafa, Tefsirde Öteki: Celâleyn'de İsrâiliyyat, Sidre Yayınları, Samsun 2008 .

Wasserstrom, Steven M., "Jewish Pseudepigrapha in Muslim Literature: A Bibliographical and Methodological Sketch", Tracing the Threads: Studies in the Vitality of Jewish Pseudepigrapha, ed. John C. Reeves, Atlanta 1994.

Winston, Robert, Tanrının Öyküsü, Say Yayınları, trc. Sinan Köseoğlu, İstanbul 2010. 
Yargıc1, Atilla, "Tefsirlerde İsrailiyyat Konusuna Eleştirel Bir Yaklaşım”, HÜIFD, cilt: 11, say1: 15 (2006).

Zehebî, Ebû Abdillah Şemsüddîn, Siyerü A'lâmi'n-Nübelâ, thk. Şuayb el-Arnaût ve dğr., Beyrut 1986.

Zehebî, Muhammed Hüseyin, el-İsrâiliyyât fi't-Tefsîr ve'l-Hadîs, Dımeşk 1985. , et-Tefsîr ve'l-Müfessirûn, Beyrut trs.

Zemahşerî, Ebu'l-Kâsım Cârullâh Mahmûd b. Ömer, el-Keşşâf 'an Hakâiki'tTenzîl, Beyrut 1977. 